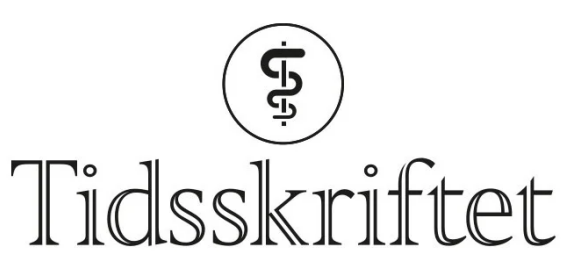

DEN NORSKE LEGEFORENING

\title{
Tiltak i grunnutdanningen for å sikre leger til distrikt - en systematisk oversikt
}

OVERSIKTSARTIKKEL

\section{BIRGIT ABELSEN}

birgit.abelsen@uit.no

Nasjonalt senter for distriktsmedisin

Institutt for samfunnsmedisin

UiT Norges arktiske universitet

Hun har bidratt med idé, utforming/design, litteratursøk, analyse og tolking av data, utarbeiding av manuset og godkjenning av innsendte manusversjon.

Birgit Abelsen er professor i helsetjenesteforskning.

Forfatteren har fylt ut ICMJE-skjemaet og oppgir ingen interessekonflikter.

\section{ANETTE FOSSE}

Nasjonalt senter for distriktsmedisin

Institutt for samfunnsmedisin

UiT Norges arktiske universitet

Hun har bidratt med idé, utforming/design, litteratursøk, analyse og tolking av data, utarbeiding av manuset og godkjenning av innsendte manusversjon.

Anette Fosse er ph.d., spesialist i allmennmedisin og senterleder.

Forfatteren har fylt ut ICMJE-skjemaet og oppgir ingen interessekonflikter.

\section{MARGRETE GASKI}

Nasjonalt senter for distriktsmedisin

Institutt for samfunnsmedisin

UiT Norges arktiske universitet

Hun har bidratt med idé, utforming/design, litteratursøk, analyse og tolking av data, utarbeiding av manuset og godkjenning av innsendte manusversjon.

Margrete Gaski er ph.d. og forsker I.

Forfatteren har fylt ut ICMJE-skjemaet og oppgir ingen interessekonflikter.

\section{HILDE GRIMSTAD}

Institutt for samfunnsmedisin og sykepleie

NTNU, Trondheim

Hun har bidratt med idé, utforming/design, litteratursøk, analyse og tolking av data, utarbeiding av manuset og godkjenning av innsendte manusversjon.

Hilde Grimstad er professor i allmenn- og atferdsmedisin og leder for PLUS (Støtte for pedagogisk, undersvisning og læring) ved NTNU, og har vært prodekan for utdanning ved samme fakultet. Hun ledet Grimstadutvalget i 2019 og er leder i programgruppen for medisinutdanning i RETHOS.

Forfatteren har fylt ut ICMJE-skjemaet og oppgir ingen interessekonflikter.

\section{BAKGRUNN}

Rekruttering av leger til distrikt er utfordrende. Ulike utdanningstiltak for å sikre leger til distrikt er etablert i mange land. Målet med denne studien var å samle kunnskap om hvilke tiltak i grunnutdanningen av leger som er etablert for å bidra til distriktsrekruttering, og hvilke resultater disse tiltakene har gitt. 
Vi gjorde et systematisk søk i databasene Cinahl, Eric, Medline og PsycInfo med søkeordene «rural», «remote», «workforce», «physicians», «recruitment» og «retention». Vi inkluderte artikler som oppfylte følgende kriterier: utdanningstiltak(ene) var tydelig beskrevet, studiepopulasjonen var uteksaminert fra grunnutdanning i medisin samt at utfallsmål omfattet arbeidssted (distrikt/ikke-distrikt) etter endt grunnutdanning.

RESULTATER

Analysen inkluderte 58 artikler og omfattet utdanningstiltak i ti land. Tiltakene var av fem hovedtyper, ofte i kombinasjoner: prioritert opptak fra distrikt, studieplan med distriktrelevant læringsutbytte, regionalisert utdanning, praksisnær læring i distrikt samt bindingstid i distrikt etter endt utdanning. I flertallet av studiene (42/58) sammenliknet man arbeidssted (distrikt/ikke-distrikt) blant leger som hadde gjennomført utdanning med og uten tiltak. Bare to av disse rapporterte om ikke-signifikante forskjeller i arbeidssted. I 26 studier var oddsratio for arbeidssted i distrikt signifikant på $5 \%$-nivå, med oddsratioer mellom 1,5 og 17,2. I 14 studier var det signifikante forskjeller i andelen med arbeidssted i distrikt/ikke-distrikt, med differanser på 11-55 prosentpoeng.

FORTOLKNING

Å dreie fokus i utdanningen mot utvikling av kunnskap, ferdigheter og undervisningsarenaer som gjør leger kompetent til å arbeide i distrikt, har betydning for rekruttering av leger til distrikt.

I Norge er det bred enighet om at hele befolkningen skal ha lik rett til likeverdige helsetjenester, uavhengig av blant annet bosted. Denne retten utfordres av problemer med å rekruttere og beholde helsepersonell i distriktskommuner og ved mindre sykehus.

Vi kjenner til ulike løsninger for å dekke legebehovet, eksempelvis med vikarstafetter og rekruttering internasjonalt. Norge har sluttet seg til Verdens helseorganisasjons kode for solidarisk rekruttering av helsepersonell. Det forplikter oss til å bygge en effektiv helsepersonellstyrke og redusere behovet for å rekruttere fra utlandet (1).

En uavhengig globalt sammensatt Lancet-kommisjon påpekte i 2010 at ulik tilgang til leger, både innad i og mellom land, var en utfordring for medisinsk utdanning internasjonalt. For å sikre at pasienter og befolkning har tilgang på legekompetanse, mente de også at utdanningene var for orientert mot kompetanseutvikling for arbeid på sykehus framfor i primærhelsetjenesten (므). Grimstadutvalget anbefalte i 2019 å ta større deler av helsetjenesten i bruk for å utdanne flere leger i Norge, og de foreslo flere desentraliserte studiemodeller (3). Slike modeller er etablert ved UiT Norges arktiske universitet (Bodøpakken i 2009, Finnmarksmodellen i 2017) og NTNU (Link i 2018).

Internasjonalt har grunnutdanningen i medisin vært tilrettelagt i minst 50 år for å styrke rekruttering av leger til distrikt. De fleste publikasjoner om utdanningstiltak for å sikre legedekning handler om tiltak i Australia, USA og Canada, men det er også artikler om tiltak i Afrika, Asia og Europa. De aktuelle utdanningstiltakene spenner bredt, fra å etablere nye utdanningsinstitusjoner der det er vanskeligst å rekruttere leger, til å la studentene leve og lære i distrikt over lengre tid. Medisinutdanningen ved Universitetet i Tromsø er beskrevet som den første hele skolen (whole school) som ble etablert for å bidra til legedekning i et område med lav legedekning, og fremheves som et europeisk særtilfelle i internasjonal sammenheng (4.).

Vi har utført en systematisk litteraturgjennomgang for å svare på forskningsspørsmålene: Hvilke tiltak i grunnutdanning av leger er etablert for å rekruttere leger til distrikt? Hvilke resultater er oppnådd?

\section{Kunnskapsgrunnlag}

I gjennomføringen brukte vi retningslinjene til PRISMA (Preferred Reporting Items for Systematic reviews and Meta-analyses) (5) og SWiM (Synthesis Without Meta-analysis) (ㅁ). Innledende litteratursøk ble gjort i Medline basert på en upublisert protokoll med inklusjons- og eksklusjonskriterier. Denne ble justert underveis, for eksempel bestemte vi å avgrense søket til grunnutdanningen i medisin og til studier med utfallsmål som omfattet arbeidssted (distrikt/ikke-distrikt) etter endt grunnutdanning. Det bidro til valg av søkeord. Vi søkte, i samarbeid med en universitetsbibliotekar, i databasene Cinahl (Ebsco), Eric (Ebsco), Medline (Ovid) og PsycInfo (Ovid) med søkeordene «rural», «remote», «workforce», "physicians», «recruitment» og «retention». Se appendiks for søkestrategiene.

Søket ble avsluttet 3. juni 2020 og var avgrenset til artikler på engelsk eller skandinaviske språk publisert i fagfellevurderte tidsskrift. Vi fikk 2101 treff etter duplikatfjerning. Artiklenes relevans ble først vurdert på bakgrunn av tittel og sammendrag. Rayyan, et elektronisk verktøy som gjør at to eller flere personer kan gjennomgå referanser blindet og uavhengig av hverandre etter bestemte inkluderings- og ekskluderingskriterier, ble benyttet i utvelgelsen. Tre av oss (BA, MG og AF) deltok i den fasen. Vi startet med en blindet vurdering av de samme 50 artiklene for å kalibrere en felles vurderingsmåte. Resterende 
artikler ble fordelt likt for utvelgelse. Vi inkluderte også 14 artikler fra eget litteraturarkiv. De 182 artiklene som ble valgt ut, ble gjennomlest i fulltekst av alle forfattere, og 58 ble inkludert. Vi inkluderte alle artikler som oppfylte følgende kriterier: utdanningstiltak(ene) var tydelig beskrevet,

studiepopulasjonen var uteksaminert fra grunnutdanning i medisin, og utfallsmål omfattet arbeidssted (distrikt/ikke-distrikt) etter endt grunnutdanning.

Vi ekskluderte studier som handlet om spesialistutdanning, andre utdanninger enn medisin samt studier med lav kvalitet (her definert som kombinasjonen få inkluderte $(<100)$ og manglende

kontrollgruppe), og studier fra samme universitet hvor andre studier ble vurdert som bedre. Figur 1 er et flytskjema som viser utvelgelsesprosessen (5). Fra de inkluderte studiene ekstraherte vi analyseresultat om kandidaters arbeidssted kategorisert som distrikt og ikke-distrikt etter endt utdanning.

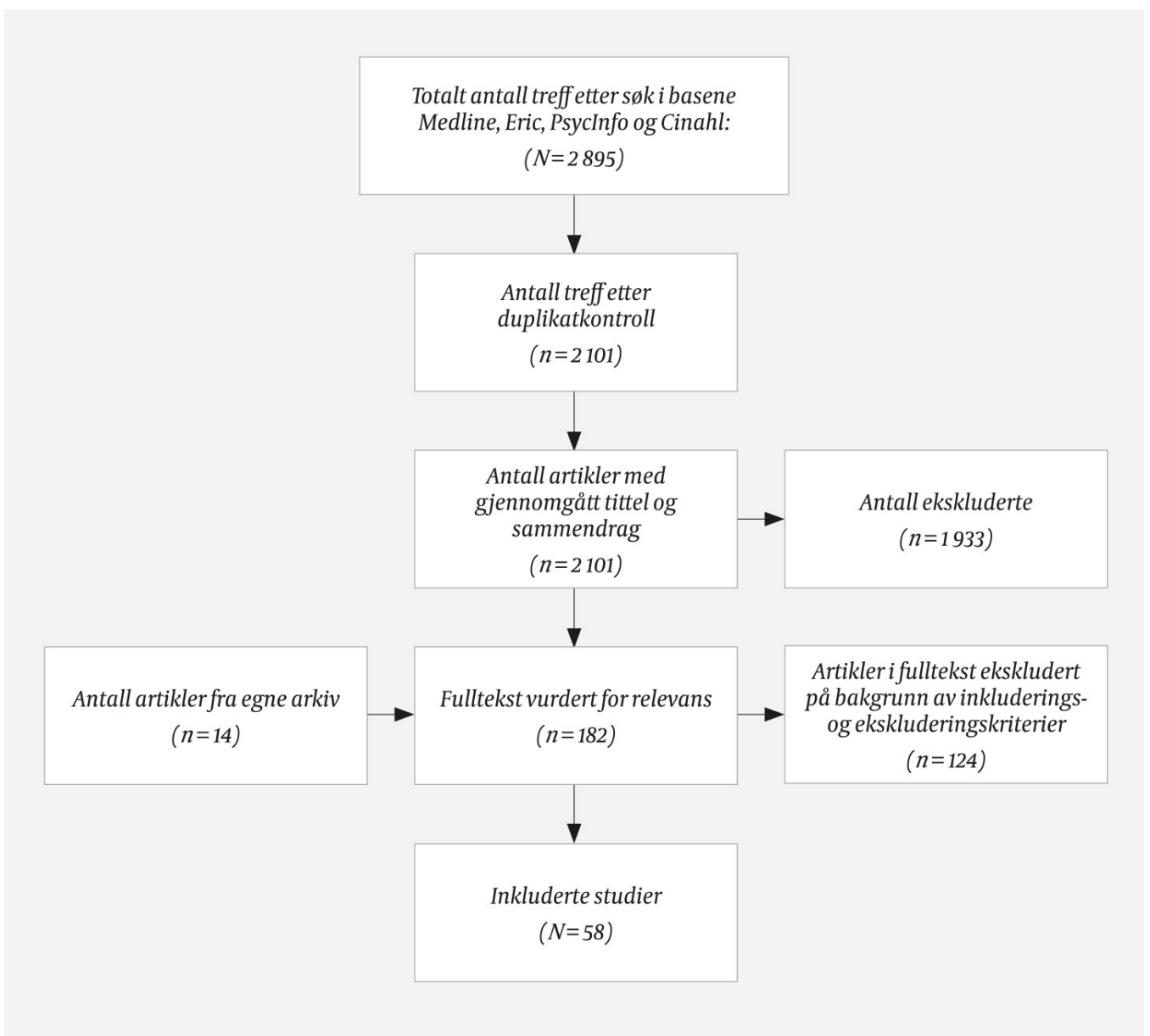

Figur 1 Flytskjema som viser fasene i den systematiske litteraturutvelgelsen.

Siden de inkluderte artiklene dokumenterer studier av ulikt design, benyttet vi narrativ syntese som analysemetode (7.). Syntesen inneholdt fire hovedelement (7, $\underline{8})$ : å beskrive og forstå utdanningstiltakene, beskrive resultatene av utdanningstiltakene slik de rapporteres i studiene på en så enhetlig måte som mulig, utforske sammenhenger i resultatene samt vurdere robustheten i syntesen.

Utdanningstiltakene ble kategorisert i fem hovedtyper. Først ble hvert av utdanningstiltakene i de inkluderte artiklene beskrevet uten å bruke kategorier. Etter første fulle gjennomlesning av artiklene formulerte vi en rekke forslag til kategorier i engelsk språkform, da artiklene var på engelsk: admission (pre-/post-), expanding medical education, rural placement/practice, whole school, commitment to work rural, curriculum, community involvement og financial support. Etter nye gjennomlesninger utviklet vi kategoriene, slik at det ble fem bedre avgrensede og mest mulig gjensidig utelukkende kategorier. Disse er beskrevet i resultatavsnittet.

Begrepet distrikt forstås gjerne generisk, men det er ikke entydig definert i litteraturen. Noen studier definerer distrikt med utgangspunkt i formelle sentralitetsindekser som skiller mellom relativ tilgang til tjenester fra ulike geografiske områder. Australian Standard Geographical Classification-Remoteness Areas (ASGC-RA) er ett eksempel. Her definerer skårene 2-5 ulike distriktsområder, og skår 1 er storbyområde. I andre studier konstrueres særegne definisjoner av distrikt. I en artikkel fra Japan (9) ble distriktskommuner definert med utgangspunkt i antall innbyggere per kvadratmeter, antall leger og størrelsen på forholdet lege: folketall. I Kongo ble et distrikt definert som et område uten en legalt utpekt ordfører (10 $)$. Disse ulikhetene gjør at studier som er basert på ulike definisjoner av distrikt, ikke er direkte sammenliknbare. Vi benytter distrikt slik det er definert i hver enkelt artikkel.

\section{Resultater}


Analysen omfattet utdanningstiltak for å sikre leger til distrikt i ti land. Til sammen var det inkludert 58 artikler fra Australia $(n=21), \operatorname{USA}(n=16)$, Canada $(n=7)$, Norge $(n=3)$, Thailand $(n=3)$, New Zealand $(n=$ 2 ), Filippinene $(n=2)$, Japan $(n=2)$, Kongo $(n=1) \operatorname{og} \operatorname{Brasil}(n=1) \cdot 38$ studier var tverrsnittsstudier, i den forstand at de unders $\emptyset$ kte arbeidssted på ett gitt tidspunkt, 18 var longitudinelle studier som unders $\emptyset$ kte arbeidssted på mer enn ett tidspunkt, og to var litteraturstudier. 42 studier bygde på registerdata og 34 studier inkluderte mer enn 500 kandidater. Studiene var publisert i perioden 1993-2019, 32 etter 2014. 47 studier handlet om kandidater fra ett enkelt universitet.

Tabell 1 oppsummerer karakteristika og resultater fra artiklene (9-66), mens tabell 2a-j gir flere detaljer.

\section{Tabell 1}

Inkluderte artikler i den systematiske oversikten og hvilke utdanningstiltak de omtaler: $1=$ prioritert opptak fra distrikt, 2 = studieplan med distriktrelevant læringsutbytte, $3=$ regionalisert utdanning, $4=$ praksisnær læring i distrikt, 5 = bindingstid i distrikt etter endt utdanning.

\begin{tabular}{|c|c|}
\hline Forfatter(e) & Utdanningstiltak \\
\hline Alexandersen et al. 2004 (11) & 3,4 \\
\hline Boonluksiri et al. 2018 (12) & $1,3,5$ \\
\hline Campbell et al. 2019 (13) & $1,2,3,4,5$ \\
\hline Clark et al. 2013 (14) & $1,3,4$ \\
\hline Crump et al. 2013 (15) & 3,4 \\
\hline Figueiredo et al. 2019 (16) & 3 \\
\hline Florence et al. 2007 (17) & 2,4 \\
\hline Fournier \& Henderson 2005 (18) & 4 \\
\hline Gaski et al. 2017 (19) & 3,4 \\
\hline Guilbault \& Vinson 2017 (20) & 4 \\
\hline Gupta et al. 2019 (21) & $1,3,4$ \\
\hline Halaas et al. 2008 (22) & $1,3,4$ \\
\hline Halili et al. 2017 (23) & 4 \\
\hline Jamar et al. 2014 (24) & $1,3,4$ \\
\hline Kitchener et al. 2015 (25) & $1,2,3,4,5$ \\
\hline Kwan et al. 2017 (26) & $1,3,4,5$ \\
\hline Longombe 2009 (10) & 3 \\
\hline Lovato et al. 2019 (27) & 3,4 \\
\hline MacDowell et al. 2013 (28) & $1,2,4$ \\
\hline Magnus \& Tollan 1993 (29) & 3,4 \\
\hline Mathews et al. 2017 (30) & $1,2,3,4$ \\
\hline Matsumoto et al. 2008a (9) & 1,5 \\
\hline Matsumoto et al. 2008b (31) & 1,5 \\
\hline Matthews et al. 2015 (32) & 1,3 \\
\hline May et al. 2018 (33) & $1,3,4$ \\
\hline McDonnel Smedts \& Lowe 2007 (34) & $1,3,4$ \\
\hline McGirr et al. 2019 (35) & $1,3,4$ \\
\hline McGrail et al. 2018 (36) & $1,3,4$ \\
\hline McKillop et al. 2017 (37) & 1,3 \\
\hline Moore et al. 2018 (38) & $1,3,4$ \\
\hline
\end{tabular}




\begin{tabular}{|c|c|}
\hline Forfatter(e) & Utdanningstiltak \\
\hline Murray et al. 2018 (39) & 4 \\
\hline Myhre et al. 2016 (40) & 3,4 \\
\hline O'Sullivan et al. 2018a (41) & $1,3,4$ \\
\hline O'Sullivan et al. 2018b (42) & $1,3,4$ \\
\hline Pagaiya et al. 2015 (43) & $1,3,5$ \\
\hline Pathman 1994 (44) & 3,4 \\
\hline Playford \& Cheong 2012 (45) & $1,3,4$ \\
\hline Playford \& Puddey 2017 (46) & $1,3,4,5$ \\
\hline Playford et al. 2014 (47) & $1,3,4$ \\
\hline Playford et al. 2015 (48) & $1,3,4$ \\
\hline Playford et al. 2016 (49) & $1,3,4$ \\
\hline Playford et al. 2019 (50) & $1,3,4,5$ \\
\hline Quinn et al. 2011 (51) & $1,2,4$ \\
\hline Rabinowitz et al. 2005 (52) & $1,2,4$ \\
\hline Rabinowitz et al. 2011 (53) & $1,2,4$ \\
\hline Ray et al. 2015 (54) & $1,3,4$ \\
\hline Rhyne et al. 2006 (55) & 4 \\
\hline Rosenblatt 1996 (56) & 5 \\
\hline Rourke et al. 2018 (57) & $1,2,3,4$ \\
\hline Sen Gupta et al. 2014 (58) & $1,3,4$ \\
\hline Smucny et al. 2005 (59) & 4 \\
\hline Tate \& Aoki $2012(60)$ & 4 \\
\hline Techakehakij \& Arora 2017(61) & $1,3,5$ \\
\hline Wendling et al. 2016 (62) & 3,4 \\
\hline Wenghofer et al. 2017 (63) & $1,2,3,4$ \\
\hline Wheat et al. 2008 (64) & $1,2,3,4$ \\
\hline Woolley et al. 2018 (65) & 4 \\
\hline Zink et al. 2010 (66) & $1,3,4$ \\
\hline
\end{tabular}

\section{Tabell 2a}

Inkluderte artikler fra Australia. Utdanningstiltak: 1 = prioritert opptak fra distrikt, 2 = studieplan med distriktrelevant læringsutbytte, 3 = regionalisert utdanning, 4 = praksisnær læring i distrikt, 5 = bindingstid i distrikt etter endt utdanning.

\begin{tabular}{|lllll|}
\hline Forfattere & $\begin{array}{l}\text { Studiepopulasjon } \\
\text { (antall inkluderte) }\end{array}$ & Utfall(datakilde) & Tiltak Design & Resultat \\
\hline
\end{tabular}




\begin{tabular}{|c|c|c|c|c|c|}
\hline Forfattere & $\begin{array}{l}\text { Studiepopulasjon } \\
\text { (antall inkluderte) }\end{array}$ & Utfall (datakilde) & Tiltal & Design & Resultat \\
\hline $\begin{array}{l}\text { McGirr et } \\
\text { al. } 2019 \\
(35)\end{array}$ & $\begin{array}{l}\text { Alle uteksaminerte } \\
\text { fra } 12 \text { universiteter } \\
\text { med rural clinical } \\
\text { school i } 2011 \text { ( } n= \\
1695)\end{array}$ & $\begin{array}{l}\text { Arbeidssted per } \\
2017 \text { (Register) }\end{array}$ & $\begin{array}{l}1,3 \\
4\end{array}$ & $\begin{array}{l}\text { Sammenliknende } \\
\text { tverrsnittsstudie }\end{array}$ & $\begin{array}{l}17 \% \text { av dem som hadde } \\
\text { gjennomført rural } \\
\text { clinical school, hadde } \\
\text { arbeidssted i distrikt. } \\
\text { Andelen med } \\
\text { arbeidssted i distrikt } \\
\text { varierte mellom } 6 \% \text { og } \\
56 \% \text { i ulike } \\
\text { universitetskohorter (p < } \\
\text { 0,001). Oddsratio (OR) } \\
\text { for at legene som hadde } \\
\text { gjennomført rural } \\
\text { clinical school og hadde } \\
\text { arbeidssted i distrikt, var } \\
\text { 1,9 (95\% KI 1,45 til 2,49) } \\
\text { sammenliknet med leger } \\
\text { som ikke hadde } \\
\text { gjennomført slik skole }\end{array}$ \\
\hline $\begin{array}{l}\text { Playford } \\
\text { et al. } 2019 \\
(50)\end{array}$ & $\begin{array}{l}\text { Alle uteksaminerte } \\
\text { leger fra University } \\
\text { of Western Australia } \\
\text { tatt opp 2004-10 (n } \\
=878 \text { ) }\end{array}$ & $\begin{array}{l}\text { Arbeidssted per } \\
2013,2014,2016, \\
2017 \text { og } 2018 \\
\text { (Register) }\end{array}$ & $\begin{array}{l}1,3 \\
4,5\end{array}$ & $\begin{array}{l}\text { Sammenliknende } \\
\text { longitudinell } \\
\text { studie, } \\
\text { inkluderer } \\
\text { arbeidssted i en } \\
\text { femårsperiode }\end{array}$ & $\begin{array}{l}\text { Lineær trend blant dem } \\
\text { med arbeidssted i } \\
\text { distrikt (stigningstall fra } \\
\text { 2013-18): urban } \\
\text { bakgrunn/ikke rural } \\
\text { clinical school 1,18 (95\% } \\
\text { KI 1,08 til 1,29), } \\
\text { distriktbakgrunn/ikke } \\
\text { rural clinical school 1,16 } \\
\text { (95\% KI 0,99 til 1,37), } \\
\text { urban bakgrunn/ rural } \\
\text { clinical school 1,04 (95\% } \\
\text { KI 0,95 til 1,14) og } \\
\text { distriktbakgrunn/rural } \\
\text { clinical school 1,23 (95\% } \\
\text { KI 1,09 til 1,40). De med } \\
\text { studieplass med binding } \\
\text { til distrikt arbeidet i } \\
\text { større grad i distrikt enn } \\
\text { dem uten (OR = 1,9; } 95 \% \\
\text { KI 1,53 til 2,40) }\end{array}$ \\
\hline $\begin{array}{l}\text { Playford \& } \\
\text { Puddey } \\
2017 \text { (46) }\end{array}$ & $\begin{array}{l}\text { Alle uteksaminerte } \\
\text { leger fra University } \\
\text { of Western Australia } \\
\text { tatt opp 2004-10 (n } \\
=1026 \text { ) }\end{array}$ & $\begin{array}{l}\text { Arbeidssted per } \\
2014 \text { (Register) }\end{array}$ & $\begin{array}{l}1,3 \\
4,5\end{array}$ & $\begin{array}{l}\text { Sammenliknende } \\
\text { tverrsnittsstudie }\end{array}$ & $\begin{array}{l}\text { Oddsratio for } \\
\text { arbeidssted i distrikt var } \\
3,0 \text { ( } 95 \% \text { KI 1,90 til 4,64) } \\
\text { for dem som hadde } \\
\text { gjennomført rural } \\
\text { clinical school og 1,1 } \\
\text { (95\% KI 0,45 til 2,67) for } \\
\text { dem som hadde søkt, } \\
\text { men ikke gjennomført } \\
\text { rural clinical school, } \\
\text { sammenliknet med dem } \\
\text { som ikke hadde noen } \\
\text { interesse for arbeid i } \\
\text { distrikt. De med } \\
\text { subsidiert studieplass } \\
\text { med binding til distrikt } \\
\text { arbeidet i større grad i } \\
\text { distrikt enn dem uten } \\
\text { (OR = 4,2; } 95 \% \text { KI 2,20 til } \\
8,06)\end{array}$ \\
\hline
\end{tabular}




\begin{tabular}{|c|c|c|c|c|c|}
\hline Forfattere & $\begin{array}{l}\text { Studiepopulasjon } \\
\text { (antall inkluderte) }\end{array}$ & Utfall (datakilde) & Tiltal & Design & Resultat \\
\hline $\begin{array}{l}\text { Playford } \\
\text { et al. } 2015 \\
(48)\end{array}$ & $\begin{array}{l}\text { Alle uteksaminerte } \\
\text { leger fra University } \\
\text { of Western Australia } \\
\text { tatt opp 1980-2011 (n } \\
=3282 \text { ) }\end{array}$ & $\begin{array}{l}\text { Arbeidssted per } \\
2014 \text { (Register) }\end{array}$ & $\begin{array}{l}1,3 \\
4\end{array}$ & $\begin{array}{l}\text { Sammenliknende } \\
\text { tverrsnittsstudie }\end{array}$ & $\begin{array}{l}\text { Oddsratio for arbeid i } \\
\text { sentralitetssone 3-5 på } \\
\text { den australske } \\
\text { sentralitetsindeksen } \\
\text { ARGC-RA (= ytre } \\
\text { regioner til svært øde) } \\
\text { var } 4,4 \text { ( } 95 \% \text { KI 2,26 til } \\
\text { 8,67) for dem som hadde } \\
\text { gjennomført rural } \\
\text { clinical school } \\
\text { sammenliknet med dem } \\
\text { uten }\end{array}$ \\
\hline $\begin{array}{l}\text { Playford } \\
\text { et al. } 2014 \\
(47)\end{array}$ & $\begin{array}{l}\text { Alle uteksaminerte } \\
\text { leger fra University } \\
\text { of Western Australia } \\
\text { tatt opp 2002-09 (n } \\
=1017 \text { ) }\end{array}$ & $\begin{array}{l}\text { Arbeidssted per } \\
2013 \text { (Register) }\end{array}$ & $\begin{array}{l}1,3 \\
4\end{array}$ & $\begin{array}{l}\text { Sammenliknende } \\
\text { tverrsnittsstudie }\end{array}$ & $\begin{array}{l}\text { Oddsratio for } \\
\text { arbeidssted i distrikt } \\
\text { blant dem som hadde } \\
\text { gjennomført rural } \\
\text { clinical school } \\
\text { sammenliknet med dem } \\
\text { som ikke hadde det, var } \\
7,5 \text { (95\% KI 3,5 til 15,8) og } \\
5,1 \text { (95\% KI 2,9 til 9,1) } \\
\text { blant leger med } \\
\text { henholdsvis } \\
\text { distriktbakgrunn og } \\
\text { urban oppvekstbakgrunn }\end{array}$ \\
\hline $\begin{array}{l}\text { Playford \& } \\
\text { Cheong } \\
2012(45)\end{array}$ & $\begin{array}{l}\text { Alle uteksaminerte } \\
\text { leger fra University } \\
\text { of Western Australia } \\
2003-07(n=490)\end{array}$ & $\begin{array}{l}\text { Arbeidssted to } \\
\text { første årene etter } \\
\text { uteksami-nering } \\
\text { (Register) }\end{array}$ & $\begin{array}{l}1,3 \\
4\end{array}$ & $\begin{array}{l}\text { Sammenliknende } \\
\text { longitudinell } \\
\text { studie, } \\
\text { inkluderer to års } \\
\text { oppfølging }\end{array}$ & $\begin{array}{l}\text { Oddsratio for } \\
\text { arbeidssted i distrikt ett } \\
\text { år etter uteksaminering } \\
\text { blant dem som hadde } \\
\text { gjennomført rural } \\
\text { clinical school var 1,5 } \\
\text { (95\% KI 0,97 til 2,38) } \\
\text { sammenliknet med dem } \\
\text { som ikke hadde } \\
\text { gjennomført slik skole. } \\
\text { To år etter } \\
\text { uteksaminering var } \\
\text { tilsvarende oddsratio 3,0 } \\
\text { (95\% KI 1,65 til 5,59) }\end{array}$ \\
\hline $\begin{array}{l}\text { Gupta et } \\
\text { al. } 2019 \\
(21)\end{array}$ & $\begin{array}{l}\text { Alle uteksaminerte } \\
\text { leger fra University } \\
\text { of Western Australia } \\
\text { med rural clinical } \\
\text { school tatt opp } \\
2002-11(n=488)\end{array}$ & $\begin{array}{l}\text { Antall rural tours i } \\
\text { 2006-20 (Register) }\end{array}$ & $\begin{array}{l}1,3 \\
4\end{array}$ & $\begin{array}{l}\text { Longitudinell } \\
\text { studie uten } \\
\text { kontrollgruppe }\end{array}$ & $\begin{array}{l}\text { En rural tour er definert } \\
\text { som en arbeidsperiode i } \\
\text { et distriktsområde av } \\
\text { minst to ukers varighet. } \\
51 \% \text { hadde gjennomført } \\
\text { én eller flere rural tours } \\
\text { og bidratt med totalt } 342 \\
\text { årsverk. } 26 \% \text { hadde } \\
\text { arbeidet i distrikt i mer } \\
\text { enn ett år }\end{array}$ \\
\hline $\begin{array}{l}\text { Playford } \\
\text { et al. } 2016 \\
\text { (49) }\end{array}$ & $\begin{array}{l}\text { Alle uteksaminerte } \\
\text { leger fra University } \\
\text { of Western Australia } \\
\text { med rural clinical } \\
\text { school tatt opp } \\
2002-12(n=417)\end{array}$ & $\begin{array}{l}\text { Arbeidssted fram } \\
\text { til } 2013 \text { (Register) }\end{array}$ & $\begin{array}{l}1,3 \\
4\end{array}$ & $\begin{array}{l}\text { Tverrsnittsstudie } \\
\text { uten } \\
\text { kontrollgruppe }\end{array}$ & $\begin{array}{l}\text { I } 2013 \text { hadde } 17 \% \\
\text { arbeidssted i distrikt. } \\
72 \% \text { hadde hatt } \\
\text { arbeidssted i distrikt } \\
\text { etter uteksaminering. I } \\
\text { gjennomsnitt var } 21 \% \text { av } \\
\text { arbeidstiden etter } \\
\text { uteksaminering } \\
\text { gjennomført i distrikt }\end{array}$ \\
\hline
\end{tabular}




\begin{tabular}{|c|c|c|c|c|c|}
\hline Forfattere & $\begin{array}{l}\text { Studiepopulasjon } \\
\text { (antall inkluderte) }\end{array}$ & Utfall (datakilde) & Tiltal & Design & Resultat \\
\hline $\begin{array}{l}\text { Clark et } \\
\text { al. } 2013 \\
\text { (14) }\end{array}$ & $\begin{array}{l}\text { Alle uteksaminerte } \\
\text { leger fra University } \\
\text { of Sidney 2005-07 ( } \\
=448 \text { ) }\end{array}$ & $\begin{array}{l}\text { Arbeidssted rett } \\
\text { etter uteksami- } \\
\text { nering (Survey, } \\
55 \% \text { svar) }\end{array}$ & $\begin{array}{l}1,3 \\
4\end{array}$ & $\begin{array}{l}\text { Sammenliknende } \\
\text { tverrsnittsstudie }\end{array}$ & $\begin{array}{l}21 \% \text { av dem som hadde } \\
\text { gjennomført rural } \\
\text { clinical school og } 10 \% \text { av } \\
\text { dem som ikke hadde } \\
\text { gjennomført slik skole, } \\
\text { startet å arbeide i distrikt } \\
\text { rett etter uteksaminering } \\
\text { ( } p=0,05) \text {. Andelen som } \\
\text { startet i distriktpraksis } \\
\text { rett etter rural clinical } \\
\text { school, var } 24 \% \text { blant } \\
\text { dem med oppvekst i } \\
\text { distrikt og } 20 \% \text { blant } \\
\text { dem med urban } \\
\text { oppvekst }\end{array}$ \\
\hline $\begin{array}{l}\text { Kwan et } \\
\text { al. } 2017 \\
(26)\end{array}$ & $\begin{array}{l}\text { Alle uteksaminerte } \\
\text { leger fra University } \\
\text { of Queensland tatt } \\
\text { opp 2002-11 }(n=729)\end{array}$ & $\begin{array}{l}\text { Tid i distrikt- } \\
\text { praksis etter } \\
\text { uteksami-nering } \\
\text { fram til } 2012 \\
\text { (Survey, } 48 \% \text { svar) }\end{array}$ & $\begin{array}{l}1,3 \\
4,5\end{array}$ & $\begin{array}{l}\text { Sammenliknende } \\
\text { longitudinell } \\
\text { studie som } \\
\text { undersøker } \\
\text { omfanget av } \\
\text { distriktpraksis } \\
\text { over tid }\end{array}$ & $\begin{array}{l}\text { Oddsratio for å være i } \\
\text { longer-term rural } \\
\text { practice blant dem som } \\
\text { hadde gjennomført rural } \\
\text { clinical school med to } \\
\text { eller ett års praksisnær } \\
\text { læring, var henholdsvis } \\
5,4(95 \% \text { KI 3,15-9,20) og } \\
2,9(95 \% \text { KI 1,77 til 4,58), } \\
\text { sammenliknet med dem } \\
\text { som ikke hadde } \\
\text { gjennomført rural } \\
\text { clinical school. De med } \\
\text { subsidiert studieplass } \\
\text { med distriktbinding } \\
\text { arbeidet i større grad i } \\
\text { distrikt enn dem uten } \\
(\text { OR = 2,1, } 95 \% \text { KI 1,19 til } \\
3,76)\end{array}$ \\
\hline $\begin{array}{l}\text { May et al. } \\
2018 \text { (33) }\end{array}$ & $\begin{array}{l}\text { Alle uteksaminerte } \\
\text { leger fra University } \\
\text { of New England og } \\
\text { University of } \\
\text { Newcastle 2012-14 (n } \\
=426 \text { ) }\end{array}$ & $\begin{array}{l}\text { Arbeidssted per } \\
\text { 2016/17 (Register) }\end{array}$ & $\begin{array}{l}1,3 \\
4\end{array}$ & $\begin{array}{l}\text { Sammenliknende } \\
\text { tverrsnittsstudie }\end{array}$ & $\begin{array}{l}10 \% \text { hadde arbeidssted i } \\
\text { distrikt. Ujustert } \\
\text { oddsratio for } \\
\text { arbeidssted i distrikt var } \\
6,3(95 \% \mathrm{KI} 2,92 \text { til } 13,56) \\
\text { for dem som hadde } \\
\text { gjennomført rural } \\
\text { clinical school, } \\
\text { sammenliknet med dem } \\
\text { som ikke hadde det. OR } \\
\text { var } 6,1 \text { ( } 95 \% \text { KI 2,72 til } \\
13,59) \text { i analysen som } \\
\text { justerte for kjønn, alder, } \\
\text { oppvekstbakgrunn og } \\
\text { binding }\end{array}$ \\
\hline $\begin{array}{l}\text { Jamar et } \\
\text { al. } 2014 \\
(24)\end{array}$ & $\begin{array}{l}\text { Alle uteksaminerte } \\
\text { leger fra University } \\
\text { of Adelaide med } \\
\text { rural clinical school } \\
\text { tatt opp 2003-10 ( } \mathrm{n}= \\
\text { 124) }\end{array}$ & $\begin{array}{l}\text { Arbeidssted etter } \\
\text { uteksami-nering til } \\
2012 \text { (Survey, } 58 \% \\
\text { svar) }\end{array}$ & $\begin{array}{l}1,3 \\
4\end{array}$ & $\begin{array}{l}\text { Longitudinell } \\
\text { studie uten } \\
\text { kontrollgruppe }\end{array}$ & $\begin{array}{l}\text { I } 2012 \text { hadde } 21 \% \\
\text { arbeidssted i distrikt. Det } \\
\text { 1., 2., 3., 4., 5., 6. og 7. året } \\
\text { etter uteksaminering } \\
\text { hadde henholdsvis } 19 \% \text {, } \\
33 \%, 32 \%, 29 \%, 37 \% \text {, } \\
26 \% \text { og } 43 \% \text { arbeidssted } \\
\text { i distrikt }\end{array}$ \\
\hline
\end{tabular}




\begin{tabular}{|c|c|c|c|c|c|}
\hline Forfattere & $\begin{array}{l}\text { Studiepopulasjon } \\
\text { (antall inkluderte) }\end{array}$ & Utfall (datakilde) & Tiltak & Design & Resultat \\
\hline $\begin{array}{l}\text { Campbell } \\
\text { et al. } 2019 \\
\text { (13) }\end{array}$ & $\begin{array}{l}\text { Alle uteksaminerte } \\
\text { leger fra Monash } \\
\text { University 2008-16 (n } \\
=2412 \text { ) }\end{array}$ & $\begin{array}{l}\text { Arbeidssted per } \\
2017 \text { (Register) }\end{array}$ & $\begin{array}{l}1,2 \\
3,4 \\
5\end{array}$ & $\begin{array}{l}\text { Sammenliknende } \\
\text { tverrsnittsstudie }\end{array}$ & $\begin{array}{l}\text { Oddsratio for } \\
\text { arbeidssted i distrikt } \\
\text { blant dem som hadde } \\
\text { rural clinical school i } \\
\text { form av longitudinal } \\
\text { integrated clerkship og } \\
\text { annen opplæring i } \\
\text { distrikt i tillegg var 5,6 } \\
\text { (95\% KI 2,81 til 11,20), } \\
\text { blant dem som hadde } \\
\text { rural clinical school i } \\
\text { form av longitudinal } \\
\text { integrated clerkship 1,7 } \\
\text { (95\% KI 0,59 til 5,04), } \\
\text { blant dem som hadde } \\
\text { rural clinical school med } \\
\text { mer enn ett år } \\
\text { praksisnær læring i } \\
\text { distrikt var den 3,0 (95\% } \\
\text { KI 1,87 til 4,77) og blant } \\
\text { dem som hadde rural } \\
\text { clinical school med ett } \\
\text { års praksisnær læring i } \\
\text { distrikt, var den 2,2 (95 \% } \\
\text { KI 1,20 til 4,19) } \\
\text { sammenliknet med dem } \\
\text { som ikke hadde rural } \\
\text { clinical school }\end{array}$ \\
\hline $\begin{array}{l}\text { McGrail et } \\
\text { al. } 2018 \\
(36)\end{array}$ & $\begin{array}{l}\text { Alle uteksaminerte } \\
\text { leger fra Monash } \\
\text { University 2008-16 (n } \\
=2451)\end{array}$ & $\begin{array}{l}\text { Arbeidssted per } \\
2017 \text { (Register) }\end{array}$ & $\begin{array}{l}1,3 \\
4\end{array}$ & $\begin{array}{l}\text { Sammenliknende } \\
\text { tverrsnittsstudie }\end{array}$ & $\begin{array}{l}\text { Oddsratio for at } \\
\text { arbeidssted var det } \\
\text { samme som sted for } \\
\text { praksisnær læring i } \\
\text { distrikt var 3,4 (95\% KI } \\
1,89 \text { til 5,98) for dem som } \\
\text { hadde praksisnær læring } \\
\text { i distrikt i } 18-24 \text { måneder } \\
\text { sammenliknet med dem } \\
\text { som hadde praksisnær } \\
\text { læring i distrikt i } \\
12 \text { måneder. Oddsratio } \\
\text { for at arbeidssted var det } \\
\text { samme som sted for } \\
\text { praksisnær læring i } \\
\text { distrikt, var } 4,5 \text { ( } 95 \% \text { KI } \\
2,14 \text { til 9,36) for dem som } \\
\text { hadde opplæring i } \\
\text { distrikt og vesentlige } \\
\text { deler av skolegangen i } \\
\text { samme område, } \\
\text { sammenliknet med dem } \\
\text { som ikke hadde slik } \\
\text { opplæring eller } \\
\text { skolegang }\end{array}$ \\
\hline
\end{tabular}




\begin{tabular}{|c|c|c|c|c|c|}
\hline Forfattere & $\begin{array}{l}\text { Studiepopulasjon } \\
\text { (antall inkluderte) }\end{array}$ & Utfall (datakilde) & Tiltak & Design & Resultat \\
\hline $\begin{array}{l}\text { O'Sullivan } \\
\text { et al. } \\
\text { 2018a (41) }\end{array}$ & $\begin{array}{l}\text { Alle uteksaminerte } \\
\text { leger fra Monash } \\
\text { University 2008-16 ( } \mathrm{n} \\
=2412 \text { ) }\end{array}$ & $\begin{array}{l}\text { Arbeidssted per } \\
2017 \text { (Register) }\end{array}$ & $\begin{array}{l}1,3 \\
4\end{array}$ & $\begin{array}{l}\text { Sammenliknende } \\
\text { tverrsnittsstudie }\end{array}$ & $\begin{array}{l}\text { Oddsratio for } \\
\text { arbeidssted i distrikt } \\
\text { økte med varigheten på } \\
\text { den praksisnære } \\
\text { læringsperioden i } \\
\text { distrikt. For dem med ett } \\
\text { år var OR 1,8 ( } 95 \% \text { KI 1,15 } \\
\text { til 2,79), for dem med } \\
>1 \text { år og < } 2 \text { år var OR 2,3 } \\
\text { (95\% KI 1,54 til 3,32) og } \\
\text { for dem med mer enn } \\
2 \text { år var OR 4,4 (95\% KI } \\
\text { 3,03 til 6,47), } \\
\text { sammenliknet med dem } \\
\text { uten rural clinical school }\end{array}$ \\
\hline $\begin{array}{l}\text { Ray et al. } \\
2015 \text { (54) }\end{array}$ & $\begin{array}{l}\text { Alle uteksaminerte } \\
\text { leger fra James Cook } \\
\text { University 2005-13 (n } \\
=856 \text { ) }\end{array}$ & $\begin{array}{l}\text { Arbeidssted per } \\
2005-2013 \\
\text { (Register/personlig } \\
\text { kontakt) }\end{array}$ & $\begin{array}{l}1,3 \\
4\end{array}$ & $\begin{array}{l}\text { Sammenliknende } \\
\text { longitudinell } \\
\text { studie }\end{array}$ & $\begin{array}{l}\text { Oddsratio for } \\
\text { arbeidssted i distrikt ett } \\
\text { år etter uteksaminering } \\
\text { var } 2,6 \text { ( } 95 \% \text { KI 1,9 til 3,6) } \\
\text { for dem med } \\
\text { oppvekststed i } \\
\text { sentralitetsområde } 3 \text { og } \\
\text { 1,8 (95\% KI 0,9 til 3,6) for } \\
\text { dem med oppvekststed i } \\
\text { sentralitetsområde } 4-5 \text {, } \\
\text { sammenliknet med dem } \\
\text { med et mer urbant } \\
\text { oppvekststed (ARGC-RA- } \\
\text { område 1-2). I det niende } \\
\text { året etter } \\
\text { uteksaminering var } \\
\text { tilsvarende OR } \\
\text { henholdsvis 4,2 (95\% KI } \\
\text { 1,3 til 13,8) og 9,5 (95\% KI } \\
\text { o,8 til 109,2) }\end{array}$ \\
\hline $\begin{array}{l}\text { Sen Gupta } \\
\text { et al. } 2014 \\
(58)\end{array}$ & $\begin{array}{l}\text { Alle uteksaminerte } \\
\text { leger fra James Cook } \\
\text { University 2005-11 (n } \\
=536 \text { ) }\end{array}$ & $\begin{array}{l}\text { Arbeidssted per } \\
\text { 2005-11 (Register) }\end{array}$ & $\begin{array}{l}1,3 \\
4\end{array}$ & $\begin{array}{l}\text { Sammenliknende } \\
\text { longitudinell } \\
\text { studie }\end{array}$ & $\begin{array}{l}\text { Etter uteksaminering } \\
\text { hadde } 60 \% \text { av total } \\
\text { arbeidstid blitt brukt i } \\
\text { distrikt. Det første året } \\
\text { etter uteksaminering } \\
\text { hadde } 69 \% \text { av dem med } \\
\text { distriktbakgrunn og } 43 \% \\
\text { av dem med urban } \\
\text { bakgrunn arbeidssted i } \\
\text { distrikt. Det } 6 . \text { og } 7 \text { året } \\
\text { etter uteksaminering } \\
\text { hadde } 67 \% \text { av dem med } \\
\text { distriktbakgrunn og } 43 \% \\
\text { av dem med urban } \\
\text { bakgrunn arbeidssted i } \\
\text { distrikt }\end{array}$ \\
\hline $\begin{array}{l}\text { Kitchener } \\
\text { et al. } 2015 \\
\text { (25) }\end{array}$ & $\begin{array}{l}\text { Alle uteksaminerte } \\
\text { leger fra Griffith } \\
\text { University 2010-13 (n } \\
=472 \text { ) }\end{array}$ & $\begin{array}{l}\text { Arbeidssted rett } \\
\text { etter uteksam- } \\
\text { inering 2011-14 } \\
\text { (Register) }\end{array}$ & $\begin{array}{l}1,2 \\
3,4 \\
5\end{array}$ & $\begin{array}{l}\text { Sammenliknende } \\
\text { tverrsnittsstudie }\end{array}$ & $\begin{array}{l}\text { Oddsratio for } \\
\text { arbeidssted i distrikt for } \\
\text { dem med rural clinical } \\
\text { school, var 11,9 ( } 95 \% \mathrm{KI} \\
6,08 \text { til } 23,32) \\
\text { sammenliknet med dem } \\
\text { som ikke gjennomførte } \\
\text { slik skole }\end{array}$ \\
\hline
\end{tabular}




\begin{tabular}{|c|c|c|c|c|c|}
\hline Forfattere & $\begin{array}{l}\text { Studiepopulasjon } \\
\text { (antall inkluderte) }\end{array}$ & Utfall (datakilde) & Tilta & Design & Resultat \\
\hline $\begin{array}{l}\text { McDonnel } \\
\text { Smedts \& } \\
\text { Lowe } \\
2007(34)\end{array}$ & $\begin{array}{l}\text { Alle uteksaminerte } \\
\text { leger fra Flinders } \\
\text { University 1999-2005 } \\
(n=452)\end{array}$ & $\begin{array}{l}\text { Første arbeidssted } \\
\text { etter uteksami- } \\
\text { nering (Register) }\end{array}$ & $\begin{array}{l}1,3 \\
4\end{array}$ & $\begin{array}{l}\text { Sammenliknende } \\
\text { tverrsnittsstudie }\end{array}$ & $\begin{array}{l}54 \% \text { av dem som } \\
\text { gjennomførte rural } \\
\text { clinical school i Northern } \\
\text { Territory, fortsatte i jobb } \\
\text { i området rett etter } \\
\text { uteksaminering, } \\
\text { sammenliknet med } 4 \% \\
\text { av dem som ikke } \\
\text { gjennomførte rural } \\
\text { clinical school i området. } \\
\text { Blant dem som ble } \\
\text { kvotert inn på slik skole i } \\
\text { Northern Territory, var } \\
\text { det } 70 \% \text { som fortsatte å } \\
\text { jobbe i området etter } \\
\text { uteksaminering. Blant } \\
\text { dem som gjennomførte } \\
\text { rural clinical school i } \\
\text { Northern Territory, men } \\
\text { ikke var kvotert inn, var } \\
\text { det } 48 \% \text { som fortsatte å } \\
\text { jobbe i området etter } \\
\text { endt utdanning }\end{array}$ \\
\hline $\begin{array}{l}\text { Moore et } \\
\text { al. } 2018 \\
(38)\end{array}$ & $\begin{array}{l}\text { Alle uteksaminerte } \\
\text { leger fra Australian } \\
\text { National University } \\
2007-17(n=965)\end{array}$ & $\begin{array}{l}\text { Arbeidssted etter } \\
\text { uteksami-nering } \\
\text { og per } 2018 \\
\text { (Register/web) }\end{array}$ & $\begin{array}{l}1,3 \\
4\end{array}$ & $\begin{array}{l}\text { Sammenliknende } \\
\text { longitudinell } \\
\text { studie }\end{array}$ & $\begin{array}{l}25 \% \text { av dem som hadde } \\
\text { gjennomført rural } \\
\text { clinical school og } 9 \% \text { av } \\
\text { dem som ikke hadde } \\
\text { gjennomført slik skole, } \\
\text { arbeidet i distrikt. Av } \\
\text { dem som hadde } \\
\text { gjennomført rural } \\
\text { clinical school, hadde } \\
38 \% \text { arbeidssted i } \\
\text { distrikt } 6-11 \text { år etter } \\
\text { uteksaminering, mens } \\
\text { tilsvarende etter 1-5 år } \\
\text { var } 16 \% \text { (p < 0,001). } \\
\text { Samme trend, at andelen } \\
\text { med arbeidssted i } \\
\text { distrikt økte over tid, ble } \\
\text { også funnet blant dem } \\
\text { som ikke hadde } \\
\text { gjennomført rural } \\
\text { clinical school: } 13 \% \\
\text { arbeidet i distrikt } 6-11 \text { år } \\
\text { etter uteksaminering, } \\
\text { mens det etter 1-5 år var } \\
5 \% \text { (p < 0,0006) }\end{array}$ \\
\hline
\end{tabular}




\begin{tabular}{|c|c|c|c|c|c|}
\hline Forfattere & $\begin{array}{l}\text { Studiepopulasjon } \\
\text { (antall inkluderte) }\end{array}$ & Utfall (datakilde) & Tiltal & Design & Resultat \\
\hline $\begin{array}{l}\text { O'Sullivan } \\
\text { et al. } \\
\text { 2018b (42) }\end{array}$ & $\begin{array}{l}\text { Studien beskriver } \\
\text { egenskapene og } \\
\text { utfallet av rural } \\
\text { clinical school, } \\
\text { inkludert forskjellige } \\
\text { effekter av ulike } \\
\text { studentkarakteristika } \\
\text { ( } 26 \text { artikler) }\end{array}$ & $\begin{array}{l}\text { Arbeidssted } \\
\text { (Litteratur-søk) }\end{array}$ & $\begin{array}{l}1,3 \\
4\end{array}$ & $\begin{array}{l}\text { Litteraturstudie } \\
\text { basert på } \\
\text { sammenliknende } \\
\text { studier }\end{array}$ & $\begin{array}{l}\text { Resultatene fra } \\
\text { litteraturgjennomgangen } \\
\text { indikerer at leger som } \\
\text { har gjennomført rural } \\
\text { clinical school, } \\
\text { konsekvent er assosiert } \\
\text { med en økt } \\
\text { sannsynlighet for } \\
\text { arbeidssted i distrikt i } \\
\text { løpet av den tidlige } \\
\text { yrkeskarrieren, } \\
\text { sammenliknet med dem } \\
\text { uten slik skole. } \\
\text { Resultatet gjelder } \\
\text { uavhengig av hvordan } \\
\text { rural clinical school er } \\
\text { strukturert Resultatene } \\
\text { tyder videre på at } \\
\text { seleksjonen av studenter } \\
\text { med oppvekst i distrikt } \\
\text { og det å tilby praksisnær } \\
\text { læring i distrikt for } \\
\text { studenter med urban } \\
\text { oppvekst, kan ytterligere } \\
\text { øke effekten av rural } \\
\text { clinical school }\end{array}$ \\
\hline
\end{tabular}

\section{Tabell 2b}

Inkluderte artikler fra USA. Utdanningstiltak: 1 = prioritert opptak fra distrikt, 2 = studieplan med distriktrelevant læringsutbytte, 3 = regionalisert utdanning, 4 = praksisnær læring i distrikt, 5 = bindingstid i distrikt etter endt utdanning.

\begin{tabular}{|c|c|c|c|c|c|}
\hline Forfattere & $\begin{array}{l}\text { Studiepopulasjon } \\
\text { (antall inkluderte) }\end{array}$ & $\begin{array}{l}\text { Utfall } \\
\text { (datakilde) }\end{array}$ & Tiltak & Design & Resultat \\
\hline $\begin{array}{l}\text { Guilbault } \\
\text { \& Vinson } \\
2017(20)\end{array}$ & $\begin{array}{l}\text { Artikler om } \\
\text { grunnutdanning i } \\
\text { medisin med } \\
\text { praksisnær læring i } \\
\text { distriktet og i } \\
\text { områder med lav } \\
\text { legedekning (10 } \\
\text { artikler) }\end{array}$ & $\begin{array}{l}\text { Arbeidssted } \\
\text { (Litteratur- } \\
\text { søk) }\end{array}$ & 4 & $\begin{array}{l}\text { Litteraturstudie } \\
\text { basert på } \\
\text { sammenliknende } \\
\text { studier }\end{array}$ & $\begin{array}{l}\text { Det var nesten tre ganger mer } \\
\text { sannsynlig at leger som hadde } \\
\text { praksisnær læring i distrikt } \\
\text { eller på steder med lav } \\
\text { legedekning i studiet, hadde } \\
\text { arbeidssted et slikt sted etter } \\
\text { spesialisering sammenliknet } \\
\text { med leger uten slik praksisnær } \\
\text { læring i studietiden (RR 2,9; } \\
95 \% \mathrm{KI} 2,17 \text { til 4,00) }\end{array}$ \\
\hline $\begin{array}{l}\text { Pathman } \\
\text { et al. } 1994 \\
(44)\end{array}$ & $\begin{array}{l}\text { Leger i primær- } \\
\text { helsetjenesten, } \\
\text { utdannet i USA } \\
1970-80 \text { og som i } \\
1981 \text { jobbet i } \\
\text { distriktspraksiser, } \\
50 \% \text { i National } \\
\text { Health Service } \\
\text { Corps ( } \mathrm{n}=303)\end{array}$ & $\begin{array}{l}\text { Arbeidssted } \\
1981 \text { og } 1990 \\
\text { (Survey, } 81 \% \\
\text { svar) }\end{array}$ & 3,4 & $\begin{array}{l}\text { Longitudinell } \\
\text { studie uten } \\
\text { kontrollgruppe }\end{array}$ & $\begin{array}{l}\text { Ingen utdanningsfaktorer var } \\
\text { assosiert med varighet av } \\
\text { arbeidssted i distrikt for dette } \\
\text { utvalget }\end{array}$ \\
\hline
\end{tabular}




\begin{tabular}{|c|c|c|c|c|c|}
\hline Forfattere & $\begin{array}{l}\text { Studiepopulasjon } \\
\text { (antall inkluderte) }\end{array}$ & $\begin{array}{l}\text { Utfall } \\
\text { (datakilde) }\end{array}$ & Tiltak & Design & Resultat \\
\hline $\begin{array}{l}\text { Rosenblatt } \\
\text { et al. } 1996 \\
(56)\end{array}$ & $\begin{array}{l}\text { Leger utdannet } \\
1980-83 \text { som } \\
\text { mottok National } \\
\text { Health Service } \\
\text { Corps- stipend på } \\
\text { medisinstudiet, } \\
\text { fullførte } \\
\text { spesialistutdanning } \\
\text { i allmennmedisin } \\
\text { og arbeidet i } \\
\text { distriktet }(n=383)\end{array}$ & $\begin{array}{l}\text { Arbeidssted } \\
\text { og varighet } \\
\text { for alt arbeid } \\
\text { fram til } 1994 \\
\text { (Survey, } 76 \% \\
\text { svar) }\end{array}$ & 5 & $\begin{array}{l}\text { Longitudinell } \\
\text { studie uten } \\
\text { kontrollgruppe }\end{array}$ & $\begin{array}{l}26 \% \text { hadde arbeidssted i det } \\
\text { distrikt de hadde fått tildelt av } \\
\text { National Health Service Corps } \\
\text { og hadde vært der i } \\
\text { gjennomsnitt i } 6,1 \text { år etter } \\
\text { fullført bindingstid. I tillegg } \\
\text { hadde } 27 \% \text { fortsatt } \\
\text { arbeidssted i distrikt }\end{array}$ \\
\hline $\begin{array}{l}\text { Florence } \\
\text { et al. } 2007 \\
(17)\end{array}$ & $\begin{array}{l}\text { Alle studenter som } \\
\text { deltok på } \\
\text { tverrprofesjonelt } \\
\text { community } \\
\text { partnership } \\
\text { program ved East } \\
\text { Tennessee State } \\
\text { University 1992- } \\
2002 \text { ( } \mathrm{n}=84 ; 24 \\
\text { leger), matchet } \\
\text { med studenter som } \\
\text { deltok på ordinært } \\
\text { studieprogram ( } \mathrm{n}= \\
\text { 168; } 36 \text { leger) }\end{array}$ & $\begin{array}{l}\text { Arbeidssted } \\
\text { per } 2002 \\
\text { (Survey, svar } \\
\text { fra } 69 \% \text { ved } \\
\text { community } \\
\text { partnership } \\
\text { program og } \\
43 \% \text { ved } \\
\text { ordinært } \\
\text { program) }\end{array}$ & 2,4 & $\begin{array}{l}\text { Sammenliknende } \\
\text { tverrsnittsstudie }\end{array}$ & $\begin{array}{l}46 \% \text { av legene med community } \\
\text { partnership program og } 31 \% \\
\text { av legene med ordinært } \\
\text { program hadde arbeidssted } i \\
\text { distrikt }(p<0,01) \text { etter } \\
\text { uteksaminering }\end{array}$ \\
\hline $\begin{array}{l}\text { Wendling } \\
\text { et al. } 2016 \\
\text { (62) }\end{array}$ & $\begin{array}{l}\text { Alle uteksaminerte } \\
\text { leger fra Michigan } \\
\text { State University } \\
\text { 1978-2006 som var } \\
\text { ferdig med } \\
\text { spesialisering } \\
\text { innen } 2011 \text { (upper } \\
\text { peninsula rural } \\
\text { physician program: } \\
\mathrm{n}=168 \text {, ordinært } \\
\text { program: } \mathrm{n}=2610 \text { ) }\end{array}$ & $\begin{array}{l}\text { Arbeidssted } \\
\text { per } 2011 \\
\text { (Register) }\end{array}$ & 3,4 & $\begin{array}{l}\text { Sammenliknende } \\
\text { tverrsnittsstudie }\end{array}$ & $\begin{array}{l}45 \% \text { av dem som hadde } \\
\text { studert ved upper peninsula } \\
\text { rural physician program og } \\
14 \% \text { av de øvrige legene hadde } \\
\text { arbeidssted i distrikt ( } \mathrm{p}< \\
0,001) \text {. Oddsratio for } \\
\text { arbeidssted i distrikt blant dem } \\
\text { med upper peninsula rural } \\
\text { physician program var } 3,09 \\
(2,12 \text { til } 4,50) \text {, sammenliknet } \\
\text { med dem fra øvrige campuser }\end{array}$ \\
\hline $\begin{array}{l}\text { Smucny et } \\
\text { al. } 2005 \\
\text { (59) }\end{array}$ & $\begin{array}{l}\text { Alle uteksaminerte } \\
\text { leger fra State } \\
\text { University of New } \\
\text { York, Upstate } \\
\text { Medical University } \\
\text { 1990-2003 (rural } \\
\text { medical education } \\
\text { program: } \mathrm{n}=132, \\
\text { ordinært program: } \\
\mathrm{n}=1969 \text { ) }\end{array}$ & $\begin{array}{l}\text { Arbeidssted } \\
\text { per } 2004 \\
\text { (Register) }\end{array}$ & 4 & $\begin{array}{l}\text { Sammenliknende } \\
\text { tverrsnittsstudie }\end{array}$ & $\begin{array}{l}\text { Større andel rural medical } \\
\text { education program-utdannede } \\
\text { hadde arbeidsted i distrikt, } \\
26 \% \text { vs. } 7 \%(p<0,0001)\end{array}$ \\
\hline $\begin{array}{l}\text { Rabinowitz } \\
\text { et al. } 2005 \\
\text { (52) }\end{array}$ & $\begin{array}{l}\text { Alle uteksaminerte } \\
\text { leger fra Thomas } \\
\text { Jefferson University } \\
\text { 1978-86 (physician } \\
\text { shortage area } \\
\text { program: } \mathrm{n}=148, \\
\text { ordinært program: } \\
\mathrm{n}=1798 \text { ) }\end{array}$ & $\begin{array}{l}\text { Arbeidssted } \\
\text { per } 2002 \text { og } \\
11-16 \text { år } \\
\text { tidligere } \\
\text { (Register) }\end{array}$ & $1,2,4$ & $\begin{array}{l}\text { Sammenliknende } \\
\text { longitudinell } \\
\text { studie }\end{array}$ & $\begin{array}{l}\text { Av } 38 \text { leger utdannet ved } \\
\text { physician shortage area } \\
\text { program som var i } \\
\text { allmennpraksis, arbeidet } 68 \% \\
\text { fortsatt i allmennpraksis i } \\
\text { samme distrikt i } 2002 \text {. } \\
\text { Tilsvarende andel for } 54 \text { leger } \\
\text { fra ordinært program var } 46 \% \\
\text { ( } p=0,03) \text {. Leger fra physician } \\
\text { shortage area program forble i } \\
\text { allmennpraksis i samme distrikt } \\
\text { lenger enn leger fra ordinært } \\
\text { program }(p=0,04)\end{array}$ \\
\hline
\end{tabular}




\begin{tabular}{|c|c|c|c|c|c|}
\hline Forfattere & $\begin{array}{l}\text { Studiepopulasjon } \\
\text { (antall inkluderte) }\end{array}$ & $\begin{array}{l}\text { Utfall } \\
\text { (datakilde) }\end{array}$ & Tiltak & Design & Resultat \\
\hline $\begin{array}{l}\text { Rabinowitz } \\
\text { et al. } 2011 \\
\text { (53) }\end{array}$ & $\begin{array}{l}\text { Alle uteksaminerte } \\
\text { leger fra Thomas } \\
\text { Jefferson University } \\
\text { 1992-2002 } \\
\text { (uteksaminerte: } \mathrm{n}= \\
2385, \text { physician } \\
\text { shortage area } \\
\text { program: } \mathrm{n}=104 \text { ) }\end{array}$ & $\begin{array}{l}\text { Arbeidssted } \\
\text { per } 2007 \\
\text { (Register) }\end{array}$ & $1,2,4$ & $\begin{array}{l}\text { Sammenliknende } \\
\text { tverrsnittsstudie }\end{array}$ & $\begin{array}{l}43 \% \text { av dem med physician } \\
\text { shortage area program og } \\
16 \% \text { av dem med ordinært } \\
\text { program arbeidet i distrikt (RR } \\
2,7 ; 95 \% \text { KI 2,1 til 3,5) }\end{array}$ \\
\hline $\begin{array}{l}\text { Fournier \& } \\
\text { Henderson } \\
2005 \text { (18) }\end{array}$ & $\begin{array}{l}\text { Alle programs in } \\
\text { medical sciences } \\
\text { (distriktsprogram)- } \\
\text { utdannede leger } \\
\text { fra University of } \\
\text { Florida 1972-92 }(n= \\
406) \text { sett mot alle } \\
\text { ordinært } \\
\text { utdannede leger } \\
\text { 1975-1995 ( } \mathrm{n}= \\
1701)\end{array}$ & $\begin{array}{l}\text { Arbeidssted } \\
\text { per } 2001 \\
\text { (Register) }\end{array}$ & 4 & $\begin{array}{l}\text { Sammenliknende } \\
\text { tverrsnittsstudie }\end{array}$ & $\begin{array}{l}4,7 \% \text { av leger med program in } \\
\text { medical sciences og } 2,4 \% \text { av } \\
\text { leger fra ordinær utdanning } \\
\text { hadde arbeidssted i distrikt, en } \\
\text { ikke-signifikant forskjell }\end{array}$ \\
\hline $\begin{array}{l}\text { Wheat et } \\
\text { al. } 2008 \\
(64)\end{array}$ & $\begin{array}{l}\text { Første kull fra rural } \\
\text { medical scholars } \\
\text { program ved } \\
\text { University of } \\
\text { Alabama }(\mathrm{n}=8)\end{array}$ & $\begin{array}{l}\text { Arbeidssted } \\
\text { per } 2004\end{array}$ & $\begin{array}{l}1,2 \\
3,4\end{array}$ & $\begin{array}{l}\text { Sammenliknende } \\
\text { tverrsnittsstudie }\end{array}$ & $\begin{array}{l}5 \text { av } 8 \text { ( } 62 \%) \text { hadde arbeidssted } \\
\text { i distrikt, mot } 14 \% \text { av de } \\
\text { ordinære studentene og } 9 \% \text { på } \\
\text { nasjonalt nivå }\end{array}$ \\
\hline $\begin{array}{l}\text { MacDowell } \\
\text { et al. } 2013 \\
(28)\end{array}$ & $\begin{array}{l}\text { Uteksaminerte } \\
\text { leger fra University } \\
\text { of Illinois 1997- } \\
\text { 2007: Rural } \\
\text { medical education } \\
\text { ( } n=160) \text {, ordinært } \\
\text { program ( } n=2663 \text { ) }\end{array}$ & $\begin{array}{l}\text { Arbeidssted } \\
\text { per } 2012 \\
\text { (Register) }\end{array}$ & $1,2,4$ & $\begin{array}{l}\text { Sammenliknende } \\
\text { tverrsnittsstudie }\end{array}$ & $\begin{array}{l}56 \% \text { av dem med rural medical } \\
\text { education praktiserte i distrikt, } \\
\text { mot } 7 \% \text { med ordinært program } \\
\text { (OR } 17,2 ; 95 \% \text { KI } 12,18 \text { til } 24,35 \text { ) }\end{array}$ \\
\hline $\begin{array}{l}\text { Crump et } \\
\text { al. } 2013 \\
(15)\end{array}$ & $\begin{array}{l}\text { Uteksaminerte } \\
\text { leger fra University } \\
\text { of Louisville i 2001- } \\
06 \text { (rural campus: } n \\
=33 \text {, ordinært } \\
\text { program: } n=759 \text { ) }\end{array}$ & $\begin{array}{l}\text { Arbeidssted, } \\
\text { årstall ikke } \\
\text { angitt } \\
\text { (Register) }\end{array}$ & 3,4 & $\begin{array}{l}\text { Sammenliknende } \\
\text { tverrsnittsstudie }\end{array}$ & $\begin{array}{l}\text { Det var seks ganger mer } \\
\text { sannsynlig at rural campus- } \\
\text { studentene hadde arbeidssted } \mathrm{i} \\
\text { distrikt }\end{array}$ \\
\hline $\begin{array}{l}\text { Halaas et } \\
\text { al. } 2008 \\
(22)\end{array}$ & $\begin{array}{l}\text { Alle uteksaminerte } \\
\text { leger fra University } \\
\text { of Minnesota fra } \\
\text { rural physician } \\
\text { associate program } \\
\text { 1971-2007 } \\
\text { (Uteksaminerte: } \mathrm{n}= \\
1175, \mathrm{i} \text { arbeid: } \mathrm{n}= \\
\text { 901) }\end{array}$ & $\begin{array}{l}\text { Arbeidssted } \\
\text { per } 2007 \\
\text { (Register) }\end{array}$ & $1,3,4$ & $\begin{array}{l}\text { Longitudinell } \\
\text { studie uten } \\
\text { kontrollgruppe }\end{array}$ & $\begin{array}{l}\text { De med rural physician } \\
\text { associate program i } \\
\text { primærhelsetjenesten hadde } \\
\text { arbeidssted i distrikt i større } \\
\text { grad enn i by ( } 56 \% \text { vs. } 44 \%, \mathrm{p}< \\
0,001 \text { ). } \\
44 \% \text { hadde praktisert i distrikt } \\
\text { hele tiden }\end{array}$ \\
\hline
\end{tabular}




\begin{tabular}{|c|c|c|c|c|c|}
\hline Forfattere & $\begin{array}{l}\text { Studiepopulasjon } \\
\text { (antall inkluderte) }\end{array}$ & $\begin{array}{l}\text { Utfall } \\
\text { (datakilde) }\end{array}$ & Tiltak & Design & Resultat \\
\hline $\begin{array}{l}\text { Zink et al. } \\
2010 \text { (66) }\end{array}$ & $\begin{array}{l}\text { Alle uteksaminerte } \\
\text { leger ved } \\
\text { University of } \\
\text { Minnesota 1990- } \\
2004 \text { ved ulike } \\
\text { campuser og rural } \\
\text { physician associate } \\
\text { program ved ulike } \\
\text { campuser (alle: } \mathrm{n}= \\
3365, \mathrm{UMN}- \\
\text { Duluth/ rural } \\
\text { physician associate } \\
\text { program: } \mathrm{n}=215, \\
\text { UMN-TC/rural } \\
\text { physician associate } \\
\text { program: } \mathrm{n}=276, \\
\text { UMN-Duluth/ikke- } \\
\text { rural physician } \\
\text { associate program: } \\
\mathrm{n}=427, \mathrm{UMN}- \\
\text { TC/ikke-rural } \\
\text { physician associate } \\
\text { program: } \mathrm{n}=2447 \text { ) }\end{array}$ & $\begin{array}{l}\text { Arbeidssted } \\
\text { per } 2007 \\
\text { (Register) }\end{array}$ & $1,3,4$ & $\begin{array}{l}\text { Sammenliknende } \\
\text { tverrsnittsstudie }\end{array}$ & $\begin{array}{l}\text { Det var høyere sannsynlighet } \\
\text { for at dem som hadde studert } \\
\text { ved distrikt-campus i Duluth og } \\
\text { hadde tatt rural physician } \\
\text { associate program, arbeidet i } \\
\text { distrikt, OR } 4,6 \text { ( } 95 \% \text { KI 3,01 til } \\
7,09 \text { ) og OR } 4,1 \text { ( } 95 \% \text { KI 2,81 til } \\
5,96) \text {, sammenliknet med de } \\
\text { andre studentene }\end{array}$ \\
\hline $\begin{array}{l}\text { Quinn et } \\
\text { al. } 2011 \text { (51) }\end{array}$ & $\begin{array}{l}\text { Uteksaminerte } \\
\text { leger fra University } \\
\text { of Missouri 1997- } \\
2006 \text { med én eller } \\
\text { flere deler av } \\
\text { distriktutdannings- } \\
\text { program }(n=108)\end{array}$ & $\begin{array}{l}\text { Første } \\
\text { arbeidssted } \\
\text { etter } \\
\text { spesialisering } \\
\text { per } 2009 \\
\text { (Register) }\end{array}$ & $1,2,4$ & $\begin{array}{l}\text { Tverrsnittsstudie } \\
\text { uten } \\
\text { kontrollgruppe }\end{array}$ & $\begin{array}{l}57 \% \text { av studentene som deltok } \\
\text { i utdanningsprogram for } \\
\text { distrikt, valgte første } \\
\text { arbeidssted i distrikt }\end{array}$ \\
\hline $\begin{array}{l}\text { Rhyne et } \\
\text { al. } 2006 \\
(55)\end{array}$ & $\begin{array}{l}\text { Uteksaminerte fra } \\
\text { University of New } \\
\text { Mexico som hadde } \\
\text { vært studenter på } \\
\text { tverrprofesjonelt } \\
\text { program i distrikt } \\
\text { 1990-2001 } \\
\text { (medisinstudenter } \\
\text { på programmet: } \mathrm{n} \\
\text { = 37, ordinært } \\
\text { program: } \mathrm{n}=63 \text { ) }\end{array}$ & $\begin{array}{l}\text { Arbeidssted, } \\
\text { årstall ikke } \\
\text { angitt } \\
\text { (Survey, } 59 \text { \% } \\
\text { svar) }\end{array}$ & 4 & $\begin{array}{l}\text { Sammenliknende } \\
\text { tverrsnittsstudie }\end{array}$ & $\begin{array}{l}\text { Det var ingen forskjell } \mathrm{i} \text { andelen } \\
\text { som valgte arbeidssted } \mathrm{i} \\
\text { distrikt blant legene }\end{array}$ \\
\hline
\end{tabular}

\section{Tabell 2c}

Inkluderte artikler fra Canada. Utdanningstiltak: 1 = prioritert opptak fra distrikt, 2 = studieplan med distriktrelevant læringsutbytte, 3 = regionalisert utdanning, 4 = praksisnær læring i distrikt, 5 = bindingstid i distrikt etter endt utdanning.

\begin{tabular}{|llll|}
\hline Forfattere & $\begin{array}{l}\text { Studiepopulasjon Utfall } \\
\text { (antall } \\
\text { inkluderte) }\end{array}$ & Tiltak Design & Resultat \\
& & \\
\hline
\end{tabular}




\begin{tabular}{|c|c|c|c|c|c|}
\hline Forfattere & $\begin{array}{l}\text { Studiepopulasjon } \\
\text { (antall } \\
\text { inkluderte) }\end{array}$ & $\begin{array}{l}\text { Utfall } \\
\text { (datakilde) }\end{array}$ & Tiltak & Design & Resultat \\
\hline $\begin{array}{l}\text { Mathews } \\
\text { et al. } 2017 \\
\text { (30) }\end{array}$ & $\begin{array}{l}\text { Alle } \\
\text { uteksaminerte } \\
\text { leger fra } \\
\text { Memorial } \\
\text { University of } \\
\text { Newfoundland } \\
\text { 1989-2008 ( }= \\
1147)\end{array}$ & $\begin{array}{l}\text { Arbeidssted } \\
\text { per } 2004 \\
\text { for } \\
\text { uteksami- } \\
\text { nerte i } \\
1989-98 \text { og } \\
\text { per } 2014 \text { for } \\
\text { uteksami- } \\
\text { nerte i } \\
\text { 1999-2008 } \\
\text { (Register) }\end{array}$ & $\begin{array}{l}1,2, \\
3,4\end{array}$ & $\begin{array}{l}\text { Tverrsnittsstudie } \\
\text { uten } \\
\text { kontrollgruppe }\end{array}$ & $\begin{array}{l}11,4 \% \text { og } 5,1 \% \text { jobbet i hhv. rurale } \\
\text { Canada og } \\
\text { Newfoundland/Labrador tidlig i } \\
\text { karrieren. I kohorten 1989-98 var } \\
\text { tallene } 13,6 \% \text { og } 6,1 \% \text { I kohorten } \\
1999-2008 \text { var tallene } 9,3 \% \text { og } \\
4,2 \% \text {. Sannsynligheten for } \\
\text { arbeidssted i rurale Canada økte } \\
\text { signifikant med rural bakgrunn og } \\
\text { spesialisering i allmennmedisin. } \\
\text { Sannsynligheten for arbeidssted i } \\
\text { Newfoundland/Labrador økte } \\
\text { signifikant med rural bakgrunn, } \\
\text { oppvekst i } \\
\text { Newfoundland/Labrador, deler } \\
\text { av/hele spesialiseringen knyttet til } \\
\text { Memorial University of } \\
\text { Newfoundland og med } \\
\text { spesialisering i allmennmedisin }\end{array}$ \\
\hline $\begin{array}{l}\text { Rourke et } \\
\text { al. } 2018 \\
(57)\end{array}$ & $\begin{array}{l}\text { Uteksaminerte } \\
\text { fra Memorial } \\
\text { University of } \\
\text { Newfoundland } \\
\text { som praktiserte } \\
\text { allmennmedisin i } \\
\text { Newfoundland } \\
\text { og Labrador i } \\
2015(n=305)\end{array}$ & $\begin{array}{l}\text { Arbeidssted } \\
\text { i } 2015 \\
\text { (Register) }\end{array}$ & $\begin{array}{l}1,2 \\
3,4\end{array}$ & $\begin{array}{l}\text { Tverrsnittsstudie } \\
\text { uten } \\
\text { kontrollgruppe }\end{array}$ & $\begin{array}{l}\text { Av alle uteksaminerte fra } \\
\text { Memorial University of } \\
\text { Newfoundland som praktiserte } \\
\text { allmennmedisin i Newfoundland } \\
\text { og Labrador i } 2015 \text {, jobbet } 36 \% \text { i } \\
\text { distriktet ( } 22 \% \text { utenfor by, } 12 \% \text { i } \\
\text { småby) og } 63 \% \text { i en mellomstor } \\
\text { by }\end{array}$ \\
\hline $\begin{array}{l}\text { Wenghofer } \\
\text { et al. } 2017 \\
(63)\end{array}$ & $\begin{array}{l}\text { Allmennleger i } \\
\text { Ontario som var } \\
\text { uteksaminert fra } \\
\text { Northern-Ontario } \\
\text { School of } \\
\text { Medicine vs. } \\
\text { andre medisinske } \\
\text { fakulteter 2009- } \\
13 \text { eller senere ( } \mathrm{n} \\
=535 \text { ) }\end{array}$ & $\begin{array}{l}\text { Arbeidssted } \\
\text { per } 2013 \\
\text { (Register) }\end{array}$ & $\begin{array}{l}1,2 \\
3,4\end{array}$ & $\begin{array}{l}\text { Sammenliknende } \\
\text { tverrsnittsstudie }\end{array}$ & $\begin{array}{l}\text { Leger som ble uteksaminert fra } \\
\text { grunnutdanningen i Northern } \\
\text { Ontario School of Medicine hadde } \\
\text { signifikant større sannsynlighet } \\
\text { for å praktisere i rurale Ontario } \\
\text { (OR 2,6; } 95 \% \text { KI 1,21 til 5,44) } \\
\text { sammenliknet med leger utdannet } \\
\text { ved andre universiteter }\end{array}$ \\
\hline $\begin{array}{l}\text { Lovato et } \\
\text { al. } 2019 \\
(27)\end{array}$ & $\begin{array}{l}\text { Alle studenter } \\
\text { tatt opp 2004-07 } \\
\text { ved University of } \\
\text { British Columbia } \\
\text { (etter at to } \\
\text { regionale } \\
\text { campuser ble } \\
\text { etablert) ( } \mathrm{n}= \\
\text { 904) }\end{array}$ & $\begin{array}{l}\text { Arbeidssted } \\
\text { per } 2014 \\
\text { (Register) }\end{array}$ & 3,4 & $\begin{array}{l}\text { Sammenliknende, } \\
\text { retrospektiv, } \\
\text { longitudinell } \\
\text { studie }\end{array}$ & $\begin{array}{l}\text { Studenter som ble utdannet på de } \\
\text { to regionale campusene hadde } \\
\text { større sannsynlighet for } \\
\text { arbeidssted i rural allmennpraksis } \\
\text { sammenliknet med studenter på } \\
\text { hovedcampus, etter at andre } \\
\text { variabler var korrigert for (OR 3,2; } \\
95 \% \text { KI 1,19 til 8,83 og OR 5,4; } 95 \% \\
\text { KI 2,24 til 12,91). Ruralt arbeidssted } \\
\text { var signifikant assosiert med rural } \\
\text { bakgrunn, men ikke med alder og } \\
\text { kjønn }\end{array}$ \\
\hline $\begin{array}{l}\text { Myhre et } \\
\text { al. } 2016 \\
(40)\end{array}$ & $\begin{array}{l}\text { Alle } \\
\text { uteksaminerte } \\
\text { leger fra } \\
\text { University of } \\
\text { Calgary 2009- } \\
2011(n=170)\end{array}$ & $\begin{array}{l}\text { Arbeidssted } \\
\text { per } 2014 \\
\text { (Register) }\end{array}$ & 3,4 & $\begin{array}{l}\text { Sammenliknende } \\
\text { tverrsnittsstudie. }\end{array}$ & $\begin{array}{l}50 \% \text { av studenter som } \\
\text { gjennomførte rural longitudinal } \\
\text { integrated clerkship hadde et } \\
\text { ruralt arbeidssted, sammenliknet } \\
\text { med } 28 \% \text { av dem som ikke } \\
\text { gjennomførte dette programmet }\end{array}$ \\
\hline $\begin{array}{l}\text { Murray et } \\
\text { al. } 2018 \\
\text { (39) }\end{array}$ & $\begin{array}{l}\text { Alle } \\
\text { uteksaminerte } \\
\text { leger fra } \\
\text { University of } \\
\text { Manitoba 2004- } \\
07(n=344)\end{array}$ & $\begin{array}{l}\text { Arbeidssted } \\
\text { fram til } \\
2016-17 \\
\text { (Register, } \\
\text { manuelt } \\
\text { søk) }\end{array}$ & 4 & $\begin{array}{l}\text { Sammenliknende } \\
\text { longitudinell } \\
\text { studie }\end{array}$ & $\begin{array}{l}\text { Oddsratio for ruralt arbeidssted } \\
\text { var } 4,0 \text { ( } 95 \% \text { KI 2,30 til 7,04) blant } \\
\text { dem som hadde deltatt i frivillige } \\
\text { rurale praksisperioder, } \\
\text { sammenliknet med dem som ikke } \\
\text { hadde det }\end{array}$ \\
\hline
\end{tabular}




\begin{tabular}{|c|c|c|c|c|c|}
\hline Forfattere & $\begin{array}{l}\text { Studiepopulasjon } \\
\text { (antall } \\
\text { inkluderte) }\end{array}$ & $\begin{array}{l}\text { Utfall } \\
\text { (datakilde) }\end{array}$ & Tiltak & Design & Resultat \\
\hline $\begin{array}{l}\text { Tate \& } \\
\text { Aoki } 2012 \\
(60)\end{array}$ & $\begin{array}{l}\text { Alle } \\
\text { uteksaminerte } \\
\text { leger fra } \\
\text { University of } \\
\text { Manitoba 1965- } \\
2000(n=2578)\end{array}$ & $\begin{array}{l}\text { Arbeidssted } \\
\text { til } 2006 \\
\text { (Survey, } \\
47 \% \text { svar) }\end{array}$ & 4 & $\begin{array}{l}\text { Sammenliknende } \\
\text { longitudinell } \\
\text { studie }\end{array}$ & $\begin{array}{l}39 \% \text { hadde hatt arbeidssted i } \\
\text { distrikt. Blant leger som hadde } \\
\text { arbeidet i allmennpraksis, hadde } \\
58 \% \text { hatt et ruralt arbeidssted. } \\
\text { Oddsratio for ruralt arbeidssted } \\
\text { for dem som hadde hatt } \\
\text { opplæring i distrikt i studiet, var } \\
1,7 \text { ( } 95 \% \text { KI 1,13 til 2,61) } \\
\text { sammenliknet med dem som ikke } \\
\text { hadde det }\end{array}$ \\
\hline
\end{tabular}

\section{Tabell 2d}

Inkluderte artikler fra Norge. Utdanningstiltak: 1 = prioritert opptak fra distrikt, 2 = studieplan med distriktrelevant læringsutbytte, 3 = regionalisert utdanning, 4 = praksisnær læring i distrikt, 5 = bindingstid i distrikt etter endt utdanning.

\begin{tabular}{|c|c|c|c|c|c|}
\hline Forfattere & $\begin{array}{l}\text { Studiepopulasjon } \\
\text { (antall } \\
\text { inkluderte) }\end{array}$ & $\begin{array}{l}\text { Utfall } \\
\text { (datakilde) }\end{array}$ & Tiltak & Design & Resultat \\
\hline $\begin{array}{l}\text { Magnus \& } \\
\text { Tollan } 1993 \\
\text { (29) }\end{array}$ & $\begin{array}{l}\text { Leger } \\
\text { uteksaminert fra } \\
\text { Universitetet i } \\
\text { Troms } \varnothing 1979- \\
1989(\mathrm{n}=350)\end{array}$ & $\begin{array}{l}\text { Arbeidssted } \\
\text { per } 1990 \\
\text { (Survey, } 84 \% \\
\text { svar) }\end{array}$ & 3,4 & $\begin{array}{l}\text { Tverrsnittsstudie } \\
\text { uten } \\
\text { kontrollgruppe }\end{array}$ & $\begin{array}{l}56 \% \text { av de uteksaminerte } \\
\text { legene arbeidet i Nord-Norge. } \\
\text { Andelen med nordnorsk } \\
\text { bakgrunn som arbeidet i Nord- } \\
\text { Norge, var } 83 \%\end{array}$ \\
\hline $\begin{array}{l}\text { Alexandersen } \\
\text { et al. } 2004 \\
\text { (11) }\end{array}$ & $\begin{array}{l}\text { Leger } \\
\text { uteksaminert fra } \\
\text { Universitetet i } \\
\text { Troms } \varnothing 1996- \\
2001(n=318)\end{array}$ & $\begin{array}{l}\text { Arbeidssted } \\
\text { per } 2003 \\
\text { (Register) }\end{array}$ & 3,4 & $\begin{array}{l}\text { Tverrsnittsstudie } \\
\text { uten } \\
\text { kontrollgruppe }\end{array}$ & $\begin{array}{l}\text { Andelen leger med nordnorsk } \\
\text { bakgrunn som arbeidet i Nord- } \\
\text { Norge, var } 75 \% \text {. De fant en } \\
\text { synkende trend for andelen } \\
\text { leger med oppvekst i Sør- } \\
\text { Norge som arbeidet i Nord- } \\
\text { Norge }\end{array}$ \\
\hline $\begin{array}{l}\text { Gaski et al. } \\
2017 \text { (19) }\end{array}$ & $\begin{array}{l}\text { Leger } \\
\text { uteksaminert fra } \\
\text { Universitetet i } \\
\text { Troms } \varnothing 1979-2012 \\
\text { som var ferdige } \\
\text { med turnus og } \\
\text { fortsatt var } \\
\text { yrkesaktive i } 2013 \\
(n=1312)\end{array}$ & $\begin{array}{l}\text { Arbeidssted } \\
\text { per } 2016 \\
\text { (geografisk } \\
\text { og i sykehus, } \\
\text { primærhelse- } \\
\text { tjeneste eller } \\
\text { annet) } \\
\text { (Register) }\end{array}$ & 3,4 & $\begin{array}{l}\text { Tverrsnittsstudie } \\
\text { uten } \\
\text { kontrollgruppe }\end{array}$ & $\begin{array}{l}\text { En større andel av Tromsø- } \\
\text { utdannede fastleger ( } 30 \% \text { ) } \\
\text { arbeidet i distriktskommuner } \\
\text { sammenliknet med alle } \\
\text { fastlegene i Norge (19\%). } \\
\text { Fastleger utdannet i Tromsø } \\
\text { bemannet } 57 \% \text { av stillingene i } \\
\text { sentrale kommuner og } 34 \% \text { av } \\
\text { stillingene i distriktskommuner } \\
\text { i Nord-Norge. En større andel } \\
\text { av Tromsø-utdannede leger i } \\
\text { helseforetak (64\%) arbeidet } \\
\text { ved universitetssykehus } \\
\text { sammenliknet med alle leger i } \\
\text { helseforetak i Norge (56\%). } \\
\text { Universitetet i Tromsø har } \\
\text { utdannet over halvparten av } \\
\text { legene som arbeidet ved } \\
\text { Universitetssykehuset Nord- } \\
\text { Norge, men kun } 14 \% \text { ved } \\
\text { sykehus i Nordland og } 28 \% \text { i } \\
\text { Finnmark }\end{array}$ \\
\hline
\end{tabular}

\section{Tabell 2e}


Inkluderte artikler fra Thailand. Utdanningstiltak: 1 = prioritert opptak fra distrikt, 2 = studieplan med distriktrelevant læringsutbytte, 3 = regionalisert utdanning, 4 = praksisnær læring i distrikt, $5=$ bindingstid i distrikt etter endt utdanning.

\begin{tabular}{|c|c|c|c|c|c|}
\hline Forfattere & $\begin{array}{l}\text { Studiepopulasjon } \\
\text { (antall } \\
\text { inkluderte) }\end{array}$ & $\begin{array}{l}\text { Utfall } \\
\text { (datakilde) }\end{array}$ & Tiltak & Design & Resultat \\
\hline $\begin{array}{l}\text { Boonluksiri } \\
\text { et al. } 2018 \\
\text { (12) }\end{array}$ & $\begin{array}{l}\text { Leger } \\
\text { uteksaminert fra } \\
\text { The collaborative } \\
\text { project to } \\
\text { increase } \\
\text { production of } \\
\text { rural doctors } \\
2001-10(\mathrm{n}= \\
10018 \text { leger; } \mathrm{n}= \\
2098 \text { fra } \\
\text { prosjektet) }\end{array}$ & $\begin{array}{l}\text { Arbeidssted } \\
\text { fire år etter } \\
\text { endt } \\
\text { utdanning } \\
\text { (Data fra de } \\
37 \text { sentre } \\
\text { for medisin- } \\
\text { utdanning) }\end{array}$ & $1,3,5$ & $\begin{array}{l}\text { Sammenliknende } \\
\text { tverrsnittsstudie }\end{array}$ & $\begin{array}{l}\text { En høyere andel fra prosjektet } \\
\text { ( } 72 \% \text { ) forble i offentlig } \\
\text { helsetjeneste enn hva gjaldt de } \\
\text { ørige legene ( } 54 \% \text { ), og særlig i } \\
\text { distrikt ( } 60 \% \text { versus } 38 \% \text { ) }\end{array}$ \\
\hline $\begin{array}{l}\text { Pagaiya et } \\
\text { al. } 2015 \text { (43) }\end{array}$ & $\begin{array}{l}\text { Alle leger } \\
\text { uteksaminert fra } \\
\text { The collaborative } \\
\text { project to } \\
\text { increase } \\
\text { production of } \\
\text { rural doctors } \mathrm{i} \\
\text { perioden 2000- } \\
07 \text { og som } \\
\text { arbeidet } \mathrm{i} \\
\text { Ministry of } \\
\text { Health etter } \\
\text { utdanning ( } \mathrm{n}= \\
7157 \text { leger ( } \mathrm{n}= \\
1093 \text { av disse fra } \\
\text { prosjektet, } \mathrm{n}= \\
6064 \mathrm{fra} \text { vanlig } \\
\text { inntak) }\end{array}$ & $\begin{array}{l}\text { Effekt av } \\
\text { prosjektet } \\
\text { a) på å bli i } \\
\text { distrikt, b) } \\
\text { på å bli i } \\
\text { offentlig } \\
\text { sektor, } \\
\text { sammen- } \\
\text { liknet med } \\
\text { øvrige } \\
\text { studenter } \\
\text { (Ministry of } \\
\text { Public } \\
\text { Health, } \\
\text { administra- } \\
\text { tive data) }\end{array}$ & $1,3,5$ & $\begin{array}{l}\text { Sammenliknende } \\
\text { tverrsnittsstudie }\end{array}$ & $\begin{array}{l}29 \% \text { av studenter fra prosjektet } \\
\text { og } 18 \% \text { andre studenter forble } \\
\text { ved sykehus i distrikt. Øvrige } \\
\text { hadde } 1,5 \text { ganger større risiko for } \\
\text { å forlate offentlig helsetjeneste } \\
\text { enn prosjektgruppen. Antatt } \\
\text { median varighet med } \\
\text { arbeidssted i distrikt var } 4,2 \text { år } \\
\text { for prosjektgruppen og 3,4 år for } \\
\varnothing v r i g e\end{array}$ \\
\hline $\begin{array}{l}\text { Techakehakij } \\
\text { \& Arora } 2017 \\
\text { (61) }\end{array}$ & $\begin{array}{l}\text { Nyutdannede } \\
\text { leger fra The } \\
\text { collaborative } \\
\text { project to } \\
\text { increase } \\
\text { production of } \\
\text { rural doctors } \\
\text { som startet i } \\
\text { offentlige } \\
\text { sykehus i } \\
\text { perioden januar } \\
2003-\text { oktober } \\
2014 \text { ( } n=15253 \text { ) }\end{array}$ & $\begin{array}{l}\text { Sammen- } \\
\text { likning av } \\
\text { årlig } \\
\text { stabilitet i } \\
\text { arbeidssted } \\
\text { og } \\
\text { sannsynlig- } \\
\text { heten for } \\
\text { treårs- } \\
\text { stabilitet } \\
\text { blant leger i } \\
\text { distrikt }\end{array}$ & $1,3,5$ & $\begin{array}{l}\text { Sammenliknende } \\
\text { longitudinell } \\
\text { studie }\end{array}$ & $\begin{array}{l}\text { De fra prosjektgruppen forble i } \\
\text { større grad i distrikt enn øvrige } \\
\text { (OR } 2,4 ; 95 \% \text { KI } 2,2 \text { til } 2,7) \text {. Blant } \\
\text { de fire gruppene tatt inn på } \\
\text { prosjektet, er det litt variasjon, } \\
\text { og gruppen graduate program } \\
\text { for civil servants forblir i distrikt i } \\
\text { størst grad }\end{array}$ \\
\hline
\end{tabular}

\section{Tabell 2f}

Inkluderte artikler fra New Zealand. Utdanningstiltak: 1 = prioritert opptak fra distrikt, $2=$ studieplan med distriktrelevant læringsutbytte, 3 = regionalisert utdanning, 4 = praksisnær læring i distrikt, 5 = bindingstid i distrikt etter endt utdanning.

\begin{tabular}{|cccc|}
\hline $\begin{array}{l}\text { Forfattere } \\
\begin{array}{l}\text { Studiepopulasjon Utfall } \\
\text { (antall }\end{array} \\
\text { inkluderte) }\end{array}$ & (datakilde) & Tiltak Design & Resultat \\
\hline
\end{tabular}




\begin{tabular}{|c|c|c|c|c|c|}
\hline Forfattere & $\begin{array}{l}\text { Studiepopulasjon } \\
\text { (antall } \\
\text { inkluderte) }\end{array}$ & $\begin{array}{l}\text { Utfall } \\
\text { (datakilde) }\end{array}$ & Tiltak & Design & Resultat \\
\hline $\begin{array}{l}\text { Matthews } \\
\text { et al. } 2015 \\
\text { (32) }\end{array}$ & $\begin{array}{l}\text { Leger som deltok } \\
\text { ved Pūkawakawa, } \\
\text { University of } \\
\text { Auckland 2008-11 } \\
\text { gjennom } \\
\text { maoriopptak, } \\
\text { distriktinntak } \\
\text { eller vanlig } \\
\text { opptak. De } \\
\text { hadde bakgrunn } \\
\text { fra distrikt/region } \\
\text { eller by }(n=45)\end{array}$ & $\begin{array}{l}\text { Arbeidssted } \\
\text { (Survey, } 62 \% \\
\text { svar) }\end{array}$ & 1,3 & $\begin{array}{l}\text { Tverrsnittsstudie } \\
\text { uten } \\
\text { kontrollgruppe }\end{array}$ & $\begin{array}{l}62 \% \text { arbeidet i distrikt eller } \\
\text { regionale områder ( } 31 \% \text { i } \\
\text { Northland). Majoriteten hadde } \\
\text { intensjoner om å arbeide i distrikt } \\
\text { eller regionalt }\end{array}$ \\
\hline $\begin{array}{l}\text { McKillop } \\
\text { et al. } 2017 \\
(37)\end{array}$ & $\begin{array}{l}\text { Leger fra } \\
\text { Pūkawakawa- } \\
\text { programmet som } \\
\text { var i sitt 1. eller } 2 . \\
\text { arbeidsår, enten } \\
\text { der de hadde } \\
\text { praksisnær } \\
\text { læring eller annet } \\
\text { sted }(n=19)\end{array}$ & $\begin{array}{l}\text { Utforsking av } \\
\text { studenter på } \\
\text { Pūkawakawas } \\
\text { fremmere og } \\
\text { hemmere for } \\
\text { å returnere til } \\
\text { det regionale } \\
\text { sykehuset } \\
\text { hvor de } \\
\text { hadde } \\
\text { praksis } \\
\text { (Survey, } \\
\text { intervju) }\end{array}$ & 1,3 & $\begin{array}{l}\text { Tverrsnittsstudie } \\
\text { uten } \\
\text { kontrollgruppe }\end{array}$ & $\begin{array}{l}15 \text { av } 19 \text { leger hadde vendt tilbake } \\
\text { til det distriktsykehuset der de } \\
\text { hadde praksis. Samsvar mellom } \\
\text { personlige mål og } \\
\text { karriereintensjoner forklarte valg } \\
\text { av arbeidssted for de fleste. Andre } \\
\text { grunner var livsstil, venner/familie } \\
\text { i nærheten samt ryktet og } \\
\text { erfaringer knyttet til Pūkawakawa- } \\
\text { programmet. Læringserfaringene } \\
\text { var viktige faktorer }\end{array}$ \\
\hline
\end{tabular}

\section{Tabell $2 g$}

Inkluderte artikler fra Filippinene. Utdanningstiltak: 1 = prioritert opptak fra distrikt, 2 = studieplan med distriktrelevant læringsutbytte, 3 = regionalisert utdanning, 4 = praksisnær læring i distrikt, 5 = bindingstid i distrikt etter endt utdanning.

\begin{tabular}{|c|c|c|c|c|c|}
\hline Forfattere & $\begin{array}{l}\text { Studiepopulasjon } \\
\text { (antall } \\
\text { inkluderte) }\end{array}$ & $\begin{array}{l}\text { Utfall } \\
\text { (datakilde) }\end{array}$ & Tiltak & Design & Resultat \\
\hline $\begin{array}{l}\text { Woolley } \\
\text { et al. } \\
2018 \text { (65) }\end{array}$ & $\begin{array}{l}\text { Leger utdannet } \\
\text { ved Ateneo de } \\
\text { Zamboanga } \\
\text { University 2003- } \\
12(n=232) \text { og } \\
\text { University of the } \\
\text { Philippines } \\
\text { Manila 1989-2013 } \\
(n=121) \text {. Alle har } \\
\text { arbeidet i minst } \\
6 \text { måneder. } \\
\text { Kontrollgruppe: } n \\
=728\end{array}$ & $\begin{array}{l}\text { Arbeidssted } \\
\text { (Skolenes } \\
\text { arkiver. Ulike } \\
\text { strategier for } \\
\text { å bestemme } \\
\text { lokalisering } \\
\text { av } \\
\text { arbeidssteder } \\
\text { (post, google } \\
\text { docs, survey, } \\
\text { Facebook)) }\end{array}$ & 4 & $\begin{array}{l}\text { Sammenliknende } \\
\text { tverrsnittsstudie }\end{array}$ & $\begin{array}{l}\text { Henholdsvis } 31 \% \text { og } 61 \% \text { av leger } \\
\text { utdannet ved Ateneo de } \\
\text { Zamboanga University og } \\
\text { University of the Philippines } \\
\text { Manila praktiserte i samfunn } \\
\text { under } 100000 \text { innbyggere i de to } \\
\text { områdene, sammenliknet med } \\
7 \% \text { og } 12 \% \text { fra konvensjonelle } \\
\text { utdanninger }\end{array}$ \\
\hline
\end{tabular}




\begin{tabular}{|c|c|c|c|c|c|}
\hline Forfattere & $\begin{array}{l}\text { Studiepopulasjon } \\
\text { (antall } \\
\text { inkluderte) }\end{array}$ & $\begin{array}{l}\text { Utfall } \\
\text { (datakilde) }\end{array}$ & Tiltak & Design & Resultat \\
\hline $\begin{array}{l}\text { Halili et } \\
\text { al. } 2017 \\
(23)\end{array}$ & $\begin{array}{l}\text { Uteksaminerte } \\
\text { leger fra Ateneo } \\
\text { de Zamboanga } \\
\text { University i 2003- } \\
12 \text { sammenliknet } \\
\text { med leger } \\
\text { uteksaminert fra } \\
\text { konvensjonell } \\
\text { medisinutdanning } \\
\text { (223 av } 232 \\
\text { uteksaminerte } \\
\text { leger var fra } \\
\text { Ateneo de } \\
\text { Zamboanga } \\
\text { University. } 119 \text { av } \\
464 \\
\text { uteksaminerte } \\
\text { leger fra } \\
\text { kontrollskole) }\end{array}$ & $\begin{array}{l}\text { Arbeidssted } \\
\text { (Survey) }\end{array}$ & 4 & $\begin{array}{l}\text { Sammenliknende } \\
\text { tverrsnittsstudie }\end{array}$ & $\begin{array}{l}\text { Legene utdannet ved Ateneo de } \\
\text { Zamboanga University hadde i } \\
\text { større grad valgt } \\
\text { medisinutdanning fordi de ønsket } \\
\text { å hjelpe andre, de kom fra lavere } \\
\text { sosioøkonomiske lag, hadde mer } \\
\text { positiv holdning til å arbeide i } \\
\text { primærhelsetjenesten, og en } \\
\text { større andel av dem arbeidet i } \\
\text { offentlig helsetjeneste eller var } \\
\text { allmennleger eller leger i distrikt }\end{array}$ \\
\hline
\end{tabular}

\section{Tabell 2h}

Inkluderte artikler fra Japan. Utdanningstiltak: 1 = prioritert opptak fra distrikt, 2 = studieplan med distriktrelevant læringsutbytte, 3 = regionalisert utdanning, 4 = praksisnær læring i distrikt, 5 = bindingstid i distrikt etter endt utdanning.

\begin{tabular}{|c|c|c|c|c|c|}
\hline Forfattere & $\begin{array}{l}\text { Studiepopulasjon } \\
\text { (antall } \\
\text { inkluderte) }\end{array}$ & $\begin{array}{l}\text { Utfall } \\
\text { (datakilde) }\end{array}$ & Tiltak & Design & Resultat \\
\hline $\begin{array}{l}\text { Matsumoto } \\
\text { et al. 2008a } \\
\text { (9) }\end{array}$ & $\begin{array}{l}\text { Uteksaminerte } \\
\text { leger fra Jichi } \\
\text { Medical } \\
\text { University 1972- } \\
91 \text { som hadde } \\
\text { fullført ni års } \\
\text { bindingstid }\end{array}$ & $\begin{array}{l}\text { Arbeidssted } \\
\text { i 2000, } \\
\text { 2004, 2006 } \\
\text { (Nasjonal } \\
\text { folketelling) }\end{array}$ & 1,5 & $\begin{array}{l}\text { Longitudinell } \\
\text { studie uten } \\
\text { kontrollgruppe }\end{array}$ & $\begin{array}{l}69,8 \% \text { av legene utdannet ved Jichi } \\
\text { Medical University slo seg ned i } \\
\text { hjemfylket. En større andel slo seg } \\
\text { ned i fylker med lav } \\
\text { befolkningstetthet eller legetetthet. } \\
\text { Det å være kvinne samt legetetthet } \\
\text { var negativt assosiert med å slå seg } \\
\text { ned i distrikt }\end{array}$ \\
\hline $\begin{array}{l}\text { Matsumoto } \\
\text { et al. } \\
2008 \mathrm{~b} \text { (31) }\end{array}$ & $\begin{array}{l}\text { Alle } \\
\text { uteksaminerte } \\
\text { leger fra Jichi } \\
\text { Medical } \\
\text { University 1978- } \\
2006(n=1255)\end{array}$ & $\begin{array}{l}\text { Arbeidssted } \\
\text { (Data fra } \\
\text { Jichi } \\
\text { Medical } \\
\text { University, } \\
\text { folketelling } \\
\text { og survey) }\end{array}$ & 1,5 & $\begin{array}{l}\text { Longitudinell } \\
\text { studie uten } \\
\text { kontrollgruppe }\end{array}$ & $\begin{array}{l}\text { Fire ganger så mange leger } \\
\text { utdannet ved Jichi Medical } \\
\text { University arbeidet i distrikt } \\
\text { sammenliknet med andre. Oppvekst } \\
\text { i distrikt samt } \\
\text { primærhelsespesialitet var positivt } \\
\text { assosiert med å arbeide i distrikt på } \\
\text { minst ett av } \\
\text { undersøkelsestidspunktene og med } \\
\text { hvor legene slo seg ned etter } \\
\text { niårskontrakten }\end{array}$ \\
\hline
\end{tabular}

\section{Tabell 2i}

Inkluderte artikler fra Den demokratiske republikken Kongo. Utdanningstiltak: $1=$ prioritert opptak fra distrikt, 2 = studieplan med distriktrelevant læringsutbytte, 3 = regionalisert utdanning, 4 = praksisnær læring i distrikt, 5 = bindingstid i distrikt etter endt utdanning.

\begin{tabular}{|llll|}
\hline Forfattere & $\begin{array}{l}\text { Studiepopulasjon Utfall } \\
\text { (antall } \\
\text { inkluderte) }\end{array}$ & Tiltak Design & Resultat \\
& & \\
\hline
\end{tabular}




\begin{tabular}{|c|c|c|c|c|c|}
\hline Forfattere & $\begin{array}{l}\text { Studiepopulasjon } \\
\text { (antall } \\
\text { inkluderte) }\end{array}$ & $\begin{array}{l}\text { Utfall } \\
\text { (datakilde) }\end{array}$ & Tiltak & Design & Resultat \\
\hline $\begin{array}{l}\text { Longombe } \\
2009 \text { (10) }\end{array}$ & $\begin{array}{l}\text { De seks første } \\
\text { kullene ved The } \\
\text { Catholic } \\
\text { University of } \\
\text { Graben og } \\
\text { L'université } \\
\text { Evangélique en } \\
\text { Afrique }(n=163)\end{array}$ & $\begin{array}{l}\text { Arbeidssted } \\
\text { (Direkte } \\
\text { kontakt med } \\
\text { Alumni og } \\
\text { myndigheter } \\
\text { i } \\
\text { provinsene) }\end{array}$ & 3 & $\begin{array}{l}\text { Sammenliknende } \\
\text { tverrsnittsstudie }\end{array}$ & $\begin{array}{l}81 \% \text { av kandidatene fra } \\
\text { medisinutdanningen rettet mot } \\
\text { distrikt arbeidet i distrikt i } \\
\text { provinsen der de hadde } \\
\text { utdanning, mens kun } 26 \% \text { av } \\
\text { kandidatene fra den urbane } \\
\text { medisinutdanningen arbeidet } i \\
\text { provinsen der de ble utdannet }\end{array}$ \\
\hline
\end{tabular}

\section{Tabell 2j}

Inkluderte artikler fra Brasil. Utdanningstiltak: $1=$ prioritert opptak fra distrikt, 2 = studieplan med distriktrelevant læringsutbytte, 3 = regionalisert utdanning, 4 = praksisnær læring i distrikt, 5 = bindingstid i distrikt etter endt utdanning.

\begin{tabular}{|c|c|c|c|c|c|}
\hline Forfattere & $\begin{array}{l}\text { Studiepopulasjon } \\
\text { (antall inkluderte) }\end{array}$ & $\begin{array}{l}\text { Utfall } \\
\text { (datakilde) }\end{array}$ & Tiltak & Design & Resultat \\
\hline $\begin{array}{l}\text { Figueiredo } \\
\text { et al. } 2019 \\
\text { (16) }\end{array}$ & $\begin{array}{l}\text { Kommuner med nye } \\
\text { medisinutdanninger } \\
(n=54) \\
\text { sammenliknet med } \\
\text { kontrollkommuner } \\
(n=408)\end{array}$ & $\begin{array}{l}\text { Endring i } \\
\text { antall leger } \\
\text { og helse- } \\
\text { institusjoner } \\
\text { per } 1000 \\
\text { innbyggere } \\
\text { fra } 2007 \text { til } \\
2016 \\
\text { (National } \\
\text { Register of } \\
\text { Healthcare } \\
\text { Establish- } \\
\text { ments) }\end{array}$ & 3 & $\begin{array}{l}\text { Sammenliknende } \\
\text { tverrsnittsstudie }\end{array}$ & $\begin{array}{l}\text { En bedre regional fordeling av } \\
\text { studieplasser }\end{array}$ \\
\hline
\end{tabular}

Tabell 3 gir en beskrivelse av hvilke fem hovedtyper av utdanningstiltak studiene omfattet. I det videre beskrives disse.

\section{Tabell 3}

Utdanningstiltak i grunnutdanningen i medisin for å sikre leger til distrikt, kategorisert i fem hovedtyper ut fra litteraturgjennomgangen.

\begin{tabular}{|ll|}
\hline Utdanningstiltak & Utdyping \\
\hline $\begin{array}{l}\text { Prioritert opptak } \\
\text { fra distrikt }\end{array}$ & $\begin{array}{l}\text { En rekke utdanningstiltak er i form av opptak, som for eksempel opptak av en større } \\
\text { andel studenter fra distrikt, der krav til stedsbakgrunn er definert på ulike måter }\end{array}$ \\
\hline $\begin{array}{l}\text { Studieplan med } \\
\text { distriktrelevant } \\
\text { læringsutbytte }\end{array}$ & $\begin{array}{l}\text { Utdanningstiltak som omhandler innhold i utdanningen, kan omfatte kunnskap, } \\
\text { ferdigheter og holdninger som er spesielt relevant for praksis i distrikt. For eksempel } \\
\text { kan det være et større fokus på vanlige allmennmedisinske problemstillinger og } \\
\text { arbeidsmåter i allmennmedisin }\end{array}$ \\
\hline $\begin{array}{l}\text { Regionalisert } \\
\text { utdanning }\end{array}$ & $\begin{array}{l}\text { Hele eller deler av utdanningen kan lokaliseres utenfor de sentrale områdene, for } \\
\text { eksempel ved desentraliserte campuser for å gjennomføre deler av utdanningen. } \\
\text { Regionalisert utdanning omfatter også opprettelse av nye utdanningsinstitusjoner i } \\
\text { regioner hvor det er legemangel (ekspandert medisinutdanning/whole school), ofte } \\
\text { kombinert med at antallet studieplasser i medisin øker. Ofte skjer regionalisering i nært } \\
\text { samarbeid med lokale myndigheter, primærhelsetjeneste og med mål om å ivareta } \\
\text { samfunnsoppdraget om å utdanne leger også til distrikt }\end{array}$ \\
\hline
\end{tabular}




\begin{tabular}{|ll|}
\hline Utdanningstiltak & Utdyping \\
\hline $\begin{array}{l}\text { Praksisnær læring } \\
\text { i distrikt }\end{array}$ & $\begin{array}{l}\text { Praksisnær læring omfatter eksternt veiledet praksis, det vil si at veileder er kliniker. } \\
\text { Klinisk undervisning inngår også i denne kategorien. Det finnes mange ulike } \\
\text { utdanningstiltak som rommer ulike former for praksisnær læring i distrikt, og tiltakene } \\
\text { har ulik varighet. Dette kan også gjelde praksisnær læring på lokale og regionale } \\
\text { sykehus fremfor universitetssykehus og sykehus i større byer. Inkludert er tiltak med } \\
\text { sommerjobb for medisinstudenter i distrikt, ordning med distriktsmentor, og tiltak hvor } \\
\text { studenten gjennomfører et utviklingsprosjekt i distrikt. }\end{array}$ \\
\hline $\begin{array}{l}\text { Bindingstid i } \\
\text { distrikt etter endt } \\
\text { utdanning }\end{array}$ & $\begin{array}{l}\text { Bindingstid et visst antall år rett etter studiet kan være kombinert med stipend til } \\
\text { studentene eller at studentenes hjemstedsregioner finansierer et antall studieplasser } \\
\text { som øremerkes for opptak av et antall studenter fra regionen. I noen land er det } \\
\text { systemer der alle har bindingstid, og noen får bindingstiden i distrikt. }\end{array}$ \\
\hline
\end{tabular}

\section{Beskrivelse av utdanningstiltakene}

\section{PRIORITERT OPPTAK FRA DISTRIKTET}

Den australske regjeringen opprettet 19 rural clinical schools i perioden 2000-15 (므.). Universiteter med slike skoler er pålagt å ta opp minst $25 \%$ studenter fra distrikt (35). Fra USA beskrives fem universiteter med prioritert opptak fra distrikt $(\underline{17}, \underline{\mathbf{2 2}}, \underline{\mathbf{2 8}}, 51,53, \underline{64}$ ), mens fra Canada beskrives to universiteter med opptakskvoter for studenter fra distrikt (57.). I New Zealand startet University of Auckland i 2008 et femårig program med fortrinnsrett for maorier og studenter fra distrikt (32). I Japan ble Jichi Medical University etablert i 1972 for å utdanne leger til arbeid i distrikt. Årlig rekrutteres 2-3 studenter fra hvert fylke, fullfinansiert av de enkelte fylkene for seks års studier (9,31). I Thailand ble The Collaborative Project to Increase Production of Rural Doctors initiert i 1994. Her rekrutteres årlig rundt 300 studenter fra distrikt (43).

STUDIEPLAN MED DISTRIKTRELEVANT LAERINGSUTBYTTE

Noen australske rural clinical schools la stor vekt på læringsutbytte relatert til primærhelsetjenesten og akuttmedisin $(\underline{13}, \underline{2} 5)$. Den ordinære medisinutdanningen vektla dette i langt mindre grad. Universiteter i USA hadde flere ulike tiltak: undervisningsfokus på helseproblemer i distrikt og et distriktfokusert

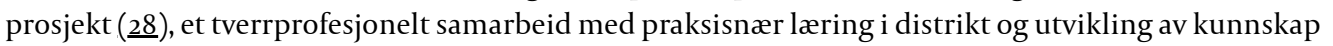
og ferdigheter for arbeid i distrikt (17.), periodiske bes $\emptyset \mathrm{k}$ i distrikt med undervisning om distriktrelaterte

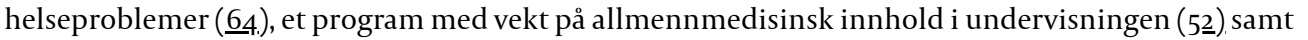
ulike valgbare utdanningsaktiviteter for distrikt: sommerprogram i lokalmiljø, klinisk praksis i distrikt og valgbar distriktpraksis (51). Universiteter i Canada hadde også studieplaner med distriktrelevant læringsutbytte $(57, \underline{6} 3)$.

\section{REGIONALISERT UTDANNING}

Rural clinical schools i Australia var enten opprettet ved et storbyuniversitet i form av desentraliserte campuser med lokalt tilsatt akademisk personell $(\underline{13}, \underline{14}, \underline{24}, \underline{26}$, , 33, 3요, $5 \underline{0}$, ,54.) eller i form av regionaliserte universitet (57.). I USA var det ulike varianter av regionalisert utdanning med desentrale campuser i distrikt under deler av studiet $(\underline{62}, \underline{64})$. Ved University of Louisville kunne 6-10 medisinstudenter årlig fullføre 3. og 4. studieår på en campus i en mindre by eller i de små lokalsamfunnene omkring (15). Tredjeårsstudentene på University of Minnesotas distriktsprogram hadde 9-12 måneder i distrikt med

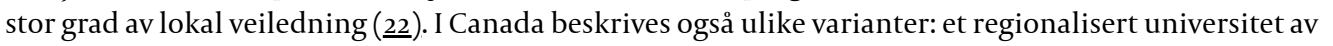
typen whole school med sterkt fokus på å utdanne leger til distrikt (57.) samt regionale campuser, helsesentre og sykehus $(\underline{2} 7, \underline{6} 3)$.

I Norge ble medisinutdanningen ved UiT Norges arktiske universitet etablert i 1973 som en regionalisert utdanning på et tidspunkt med stor legemangel i Nord-Norge (299.). Studentene ved The Collaborative Project to Increase Production of Rural Doctors, Thailand, fikk sin utdanning nært hjembyene. De tre første årene var alle studentene på samme utdanningssted. De tre siste årene var studentene på regionalog distriktssykehus i alle deler av Thailand, mens øvrige studenter hadde klinisk rotasjon på universitetssykehus og i større byer (43). University of Auckland tok opp 24 femteårsstudenter som bodde og lærte i Northland, det meste av tiden på et sykehus og med sju uker med allmennmedisin (32).

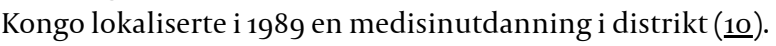

Myndighetene i Brasil etablerte i 2013 The More Doctors for Brazil Programme for å øke antallet studieplasser, antallet spesialistutdanningsprogram, antallet leger i primærhelsetjenesten i områder med få leger og for å sikre at innholdet i medisinutdanningen var tilpasset behovene $\mathrm{i}$ 
primærhelsetjenesten. Målet var å øke legetettheten til 2,7 leger per 1 ooo innbyggere og skape rundt 11500 nye studieplasser i medisin. Det ble utformet kriterier for lokalisering av nye medisinutdanninger $(\underline{16})$.

PRAKSISNAER LAERING I DISTRIKT

Universitetene i Australia med rural clinical school var forpliktet til å sikre at minst $25 \%$ av studentene ble tilbudt praksisnære læringsperioder i distrikt av minst ett års varighet. De to dominerende modellene var rotasjoner på ulike avdelinger ved lokalsykehus, i noen tilfeller kombinert med allmennpraksis, og allmennpraksis i lokalsamfunn i form av longitudinal integrated clerkships. I tillegg måtte minst $50 \%$ av studentene ved universitetet totalt sett ha minst fire uker praksisnær læring i distrikt $(35,41$ ).

I USA hadde alle universitetene i de inkluderte studiene tilbud om praksisnær læring i distrikt, men plassering i studieløpet, omfang, organisering og om aktiviteten foregikk i allmennmedisin varierte i stor grad mellom de ulike universitetene $(\mathbf{1 3}, \underline{15}, \mathbf{1 7}, \mathbf{1} \mathbf{1}, 35,4 \underline{4})$. For eksempel hadde University of Florida tidlig klinisk eksponering for distriktsmedisin på legekontor og helsesentre (묘), mens i Louisville hadde studentene på distriktcampus all praksisnær læring i distrikt i 3. og 4. studieår (15). Fra Canada beskrives også ulike varianter: et nært samarbeid med kommunene, praksisnær læring og mye desentralisert

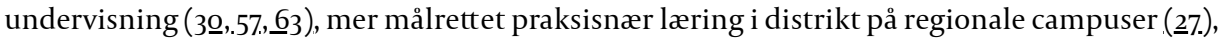
longitudinal integrated clerkships med mulighet for distriktprofil og praksisnær læring i distrikt i ett år og fokus på at studentene fikk møte leger med god undervisnings- og veilederkompetanse med distriktfokus (4으), samt praksisnære læringsperioder av ulike lengder eller sommerjobb i distrikt og distriktmentorordning $(39, \underline{60})$.

I Norge har et kjennetegn ved UiT Norges arktiske universitets medisinutdanning siden oppstarten i 1973 vært tidlig pasientkontakt og praksis i primærhelsetjenesten og ved lokalsykehus (19.).

På Filippinene utviklet to universiteter utdanninger som svarte på samfunnsoppdraget med å dekke lokale legebehov. Studentene ved det ene universitetet tilbrakte én måned per semester i praksisnær læring i distrikt i studieår 1-3 og ti måneder det fjerde året, inkludert gjennomføring av et lokalt utviklingsprosjekt. Det andre universitetet inkluderte seks måneders praksisnær læring i distrikt studieår 2, et ettårig klinisk turnusopphold og et ettårig turnusopphold det siste året (ㅁ5).

BINDINGSTID I DISTRIKT

Australske medisinstudenter kunne søke statlig subsidierte studieplasser med bindingstid i distrikt. Denne måtte gjennomføres i løpet av 18 år etter uteksaminering. Studieplassene var ikke koblet til noen rural clinical school, men studenter ved disse skolene kunne ha en subsidiert studieplass. Noen av de australske studiene undersøkte om valg av arbeidssted var assosiert med om legene hadde hatt en

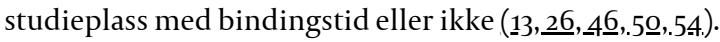

Ved National Health Service Corps-programmet i USA kunne studenter søke stipend mot bindingstid i områder med lav legedekning etter grunnutdanning (444, $5 \underline{6}$ ). Alle utdannet ved jichi Medical University i Japan hadde ni års plikttjeneste i offentlige sykehus eller distriktpraksis i hjemfylket. Dette inkluderte vanligvis tre års turnustjeneste. De som avbrøt bindingstiden, måtte betale tilbake utdanningskostnadene (31). I Thailand var alle som hadde studert medisin, tilpliktet tre års bindingstid innenfor Ministry of Health. Alternativet var en bot. Utdannede fra The Collaborative Project to Increase Production of Rural Doctors måtte returnere til hjemprovinsen. Øvrige kunne velge mellom andre tilgjengelige stillinger (43).

OPPSUMMERING AV TILTAKENE

Oversikten viser at det mest vanlige utdanningstiltaket var praksisnær læring i distrikt ( 48 studier). Dernest kom regionalisert utdanning (42 studier), prioritert opptak fra distrikt (38 studier), studieplan med distriktrelevant læringsutbytte (11 studier) og bindingstid (11 studier). Kombinasjoner av utdanningstiltak forekom ofte. 47 studier omfattet mer enn ett utdanningstiltak, 36 studier omfattet tre eller flere tiltak. Noen land, som Australia og Thailand, hadde samme utdanningstiltak ved flere universitet. Andre land hadde unike tiltak ved enkeltuniversiteter og tiltak som gjaldt uavhengig av universitet.

\section{Resultater av utdanningstiltakene}

42 studier sammenliknet arbeidssted (distrikt vs. ikke-distrikt) blant leger som hadde gjennomført utdanning med og uten tiltak. I bare to av disse ble det rapportert om ikke-signifikante forskjeller i andelen som arbeidet i distrikt $(\underline{18}, 55)$. I 26 studier $(\underline{13}, \underline{15}, \underline{20}, \underline{25})(\underline{25}-\underline{28}),(\underline{28}, 31,33,35,3 \underline{6}, 39,4 \underline{1}, 4 \underline{2}, 45)(45=$ $4 \underline{8}),(4 \underline{8}, 5 \underline{0}, 53,54, \underline{60})(\underline{60}-63),(\underline{66})$ var oddsratio (OR) for arbeidssted i distrikt statistisk signifikant på 5 \%-nivå, og oddsratio varierte mellom 1,5 og 17,2. Videre ble det i 14 studier rapportert $(\underline{6} 3, \underline{66})$ om signifikante forskjeller (på $5 \%$-nivå) i andelen med arbeidssted i distrikt mellom dem som var omfattet av utdanningstiltak og dem som ikke var det. Differansen varierte mellom 11 og 55 prosentpoeng. 
I 15 studier var det bare de som hadde gjennomført en utdanning med tiltak som ble undersøkt. Her ble andelen med arbeidssted i distrikt på ett eller flere tidspunkt rapportert. Av disse var seks (9, 11, 19, 29, 31, 57.) whole school-studier, hvor andelen varierte mellom $19,7 \%$ og $79 \%$.

Resultatene fra de inkluderte studiene er ikke direkte sammenliknbare, blant annet fordi det var stor variasjon i hvor lang tid etter uteksaminering arbeidssted var undersøkt (fra rett etter og opptil 41 år etter uteksaminering). To av de ikke-signifikante sammenlikningsstudiene inkluderte kun tiltaket praksisnær læring i distrikt (4으, $\underline{6}$ ). Majoriteten av sammenlikningsstudiene med signifikante forskjeller kombinerte mer enn ett tiltak.

SAMMENHENGER I RESULTATENE

Resultatene gir ikke grunnlag for å isolere effekter av enkelttiltak, fordi tiltakene gjerne kombineres i komplekse, kontekstavhengige intervensjoner. Det er ikke kun én versjon av et utdanningstiltak, men mange, og tiltakene er i noen grad dynamiske, det vil si endret over tid. Noen studier kan tyde på en dose-respons-effekt, altså at mer omfattende og gjennomgående tiltak gir bedre legedekning $\mathrm{i}$ rekrutteringssvake områder ( $\underline{68})$. Variasjon i kontekst og utforming og gjennomføring av studiene gjør det altså vanskelig å peke på tiltak som har større effekt enn andre.

ROBUSTHETEN I SYNTESEN

Syntesen bygger på en litteraturstudie med tre tydelige inklusjonskriterier. Majoriteten av studiene som er inkludert, bygger på registerdata og sammenlikner kandidater som har vært omfattet av utdanningstiltak og kandidater som ikke har det. Nesten alle disse viser at andelen med arbeidssted i distrikt var signifikant høyere blant dem som var omfattet av tiltak sammenliknet med dem som ikke var det. Vi har i tillegg inkludert større deskriptive studier uten kontrollgruppe. Ingen studier bygger på randomiserte, kontrollerte fors $\emptyset$ k. Det gjør at vi ikke kan konkludere med at det er kausal sammenheng mellom tiltak og arbeidssted i distrikt. Den lite systematiske utforskingen av effekter som kan tilskrives det enkelte tiltak og kombinasjoner av tiltak i disse studiene, gjør at vi ikke kommer lenger enn en konklusjon om hvilke tiltak som har vært brukt, og at tiltakene i varierende kombinasjoner er assosiert med økt tilbøyelighet blant uteksaminerte til å velge distrikt som arbeidssted.

\section{Diskusjon}

I vårt systematiske søk fant vi studier fra ti land som har utviklet medisinutdanningsvarianter med mål om styrket legedekning i distrikt. De fleste utdanningstiltakene handlet om å gi medisinstudenter mer erfaring fra distrikt gjennom studiet. Andre tiltak var prioritert opptak og bindingstid. En fellesbegrunnelse for tiltak synes å være at ordinære utdanningsopplegg ikke stimulerer medisinstudenter tilstrekkelig til fagutøvelse i distrikt etter endt utdanning. Flere av studiene brukte begrepet social accountability om utdanningen, i betydningen at utdanning av leger ikke bare er et anliggende for universitetet og universitetssykehuset, men et samfunnsoppdrag om å utdanne leger til alle typer legearbeid til hele befolkningen.

Studiene viste at hvem som tas opp, hvor og hva slags undervisning og erfaring studentene får, har betydning for valg av arbeidssted. Målrettede endringer av utdanningsinnhold og lokalisering av utdanningen har innvirkning på om leger velger å arbeide i distrikt. De fleste studiene i oversikten er fra enkeltuniversiteter som har fulgt egne studenter. Dette gir i noen tilfeller små studier, studier uten kontrollgrupper og fare for skjevhet i tolkningen av resultatene. Men det er også omfattende og solide sammenliknende registerstudier i oversikten.

Vår framgangsmåte har synliggjort metodiske svakheter i forskningen på dette feltet. Oversikten inkluderer mange tverrsnittsstudier der man undersøker arbeidssted på ett bestemt tidspunkt. Det er ingen systematikk i hvor lenge etter uteksamineringen dette tidspunktet er, og tidsintervallet fra uteksaminering til dette gitte tidspunktet varierer i studiene. Det vanskeliggjør sammenlikning av resultat og gir ingen informasjon om stabilitet i arbeidssted over tid. Det er også en svakhet at studiene i liten grad ser på skjevheter i opptaket knyttet til kandidaters interesse for arbeid i distrikt før de tas opp på utdanninger med aktuelle utdanningstiltak. En ytterligere svakhet er at studiene ikke peker på enkelttiltak eller kombinasjoner av tiltak med større effekt enn andre.

Våre funn gir oversikt over tiltak som kan tilpasses norsk kontekst. De norske studiene bekrefter de internasjonale resultatene. Etablering av medisinutdanning i Nord-Norge har gitt legerekruttering til landsdelen. Effekten er imidlertid størst for universitetsbyen Troms $\emptyset$ (19.). Prioritert opptak fra distrikt utover tilknytning til landsdel samt bindingstid knyttet til grunnutdanningen, er ikke vanlig i Norge. Litteraturoversikten viser betydningen av å dreie utdanningen mot kunnskap, ferdigheter og undervisningsarenaer som ikke er lett tilgjengelig på universitetssykehusene. Desentralisering av utdanningen kan gi større tilfang av leger til distrikt. Dette understøtter desentraliseringen som har skjedd ved UiT Norges arktiske universitet og NTNU, og liknende planer ved universitetene i Oslo og Bergen, og som Grimstadutvalget (3) har foreslått mer av til områder med legemangel. Mer kunnskap om 
legemangelen, mer praksisnær læring i distrikt, som allerede foregår i en viss utstrekning ved de fire medisinutdanningene i Norge, og studieplaner med distriktrelevant læringsutbytte kan bidra ytterligere.

Artikkelen er fagfellevurdert.

HOVEDFUNN

Vi identifiserte fem hovedtyper tiltak i medisinstudiet som er assosiert med økt tilbøyelighet blant uteksaminerte til å velge distrikt som arbeidssted: prioritert opptak fra distrikt, distriktrelevant studieplan, regionalisert utdanning, praksisnær læring i distrikt samt bindingstid i distrikt etter endt utdanning.

Nesten alle studiene viste at andelen som arbeidet i distrikt, var høyere blant legene med rekrutteringstiltak under medisinstudiet enn blant dem uten.

Resultatene ga ikke grunnlag for å isolere effekter av enkelttiltak, fordi tiltakene gjerne kombineres i komplekse, kontekstavhengige intervensjoner.

\section{LITTERATUR}

1. WHO Global Code of Practice on the International Recruitment of Health Personnel. https://www.who.int/hrh/migration/code/WHO_global_code_of_practice_EN.pdf Lest 24.6.2021.

2. Frenk J, Chen L, Bhutta ZA et al. Health professionals for a new century: transforming education to strengthen health systems in an interdependent world. Lancet 2010; 376:1923-58. [PubMed][CrossRef]

3. Grimstadutvalget. Studieplasser i medisin i Norge. Behov, modeller og muligheter. Oslo: Kunnskapsdepartementet, 2019.

https://www.regjeringen.no/contentassets/gb5b81d102384507b8515of2eofibo89/117459oo_rapport_utredning_fra_gri mstadutvalget.pdf Lest 24.6.2021.

4. Carson DB, Schoo A, Berggren P. The 'rural pipeline' and retention of rural health professionals in Europe's northern peripheries. Health Policy 2015; 119: 1550-6. [PubMed][CrossRef]

5. Liberati A, Altman DG, Tetzlaff J et al. The PRISMA statement for reporting systematic reviews and meta-analyses of studies that evaluate healthcare interventions: explanation and elaboration. BMJ 2009; 339: b270o. [PubMed] [CrossRef]

6. Campbell M, McKenzie JE, Sowden A et al. Synthesis without meta-analysis (SWiM) in systematic reviews: reporting guideline. BMJ 2020;368: 1689o. [PubMed][CrossRef]

7. Ryan R. Cochrane Consumers and Communication Review Group: data synthesis and analysis. Cochrane Consumers and Communication Review Group, 2013.

https://cccrg.cochrane.org/sites/cccrg.cochrane.org/files/public/uploads/Analysis.pdf Lest 24.6.2021.

8. Popay J, Roberts H, Sowden A et al. Guidance on the Conduct of Narrative Synthesis in Systematic Reviews. ESRC Methods Programme, 20o6. https://www.lancaster.ac.uk/media/lancaster-university/contentassets/documents/fhm/dhr/chir/NSsynthesisguidanceVersion1-April20o6.pdf Lest 24.6.2021.

9. Matsumoto M, Inoue K, Kajii E. A contract-based training system for rural physicians: follow-up of Jichi Medical University graduates (1978-2006). J Rural Health 2008; 24:36o-8. [PubMed][CrossRef]

10. Longombe AO. Medical schools in rural areas-necessity or aberration? Rural Remote Health $2009 ; 9: 1131$. [PubMed]

11. Alexandersen $\emptyset$, Jørgensen E, Østerås J et al. Medisinerutdanningen i Troms $\emptyset$-sikrer den legerekrutteringen til Nord-Norge? Tidsskr Nor Laegeforen 2004; 124: 2107-9. [PubMed]

12. Boonluksiri P, Tumviriyakul H, Arora R et al. Community-based learning enhances doctor retention. Educ Health (Abingdon) 2018; 31: 114-8. [PubMed][CrossRef]

13. Campbell DG, McGrail MR, O'Sullivan B et al. Outcomes of a 1-year longitudinal integrated medical clerkship in small rural Victorian communities. Rural Remote Health 2019; 19: 4987. [PubMed][CrossRef]

14. Clark TR, Freedman SB, Croft AJ et al. Medical graduates becoming rural doctors: rural background versus extended rural placement. Med J Aust 2013; 199: 779-82. [PubMed][CrossRef]

15. Crump WJ, Fricker RS, Ziegler C et al. Rural track training based at a small regional campus: equivalency of training, residency choice, and practice location of graduates. Acad Med 2013; 88: 1122-8. [PubMed][CrossRef]

16. Figueiredo AM, McKinley DW, Lima KC et al. Medical school expansion policies: educational access and physician distribution. Med Educ 2019; 53: 1121-31. [PubMed][CrossRef]

17. Florence JA, Goodrow B, Wachs J et al. Rural health professions education at East Tennessee State University: survey of graduates from the first decade of the community partnership program. J Rural Health 2007; 23: 77-83. [PubMed][CrossRef]

18. Fournier GM, Henderson C. Incentives and physician specialty choice: a case study of Florida's Program in Medical Sciences. Inquiry 2005; 42: 160-70. [PubMed][CrossRef]

19. Gaski M, Halvorsen P, Aaraas I et al. Utdanner Universitetet i Troms $\emptyset$ - Norges arktiske universitet leger til à arbeide i distrikter? Tidsskr Nor Legeforen 2017; 137: 1026-31. 
20. Raymond Guilbault RW, Vinson JA. Clinical medical education in rural and underserved areas and eventual practice outcomes: A systematic review and meta-analysis. Educ Health (Abingdon) 2017;30: 146-55. [PubMed] [CrossRef]

21. Gupta S, Ngo H, Burkitt T et al. Survival analysis of Rural Clinical School of Western Australia graduates: the longterm work of building a long-term rural medical workforce. BMC Health Serv Res 2019; 19: 998. [PubMed][CrossRef]

22. Halaas GW, Zink T, Finstad D et al. Recruitment and retention of rural physicians: outcomes from the rural physician associate program of Minnesota. J Rural Health 2008; 24:345-52. [PubMed][CrossRef]

23. Halili S, Cristobal F, Woolley T et al. Addressing health workforce inequities in the Mindanao regions of the Philippines: Tracer study of graduates from a socially-accountable, community-engaged medical school and graduates from a conventional medical school. Med Teach 2017;39: 859-65. [PubMed][CrossRef]

24. Jamar E, Newbury J, Mills D. Early career location of University of Adelaide rural cohort medical students. Rural Remote Health 2014; 14: 2592. [PubMed][CrossRef]

25. Kitchener S, Day R, Faux D et al. Longlook: initial outcomes of a longitudinal integrated rural clinical placement program. Aust J Rural Health 2015; 23: 169-75. [PubMed][CrossRef]

26. Kwan MMS, Kondalsamy-Chennakesavan S, Ranmuthugala G et al. The rural pipeline to longer-term rural practice: General practitioners and specialists. PLoS One 2017; 12: e0180394. [PubMed][CrossRef]

27. Lovato $\mathrm{CY}, \mathrm{Hsu} \mathrm{HCH}$, Bates J et al. The regional medical campus model and rural family medicine practice in British Columbia: a retrospective longitudinal cohort study. CMAJ Open 2019; 7: E415-20. [PubMed][CrossRef]

28. MacDowell M, Glasser M, Hunsaker M. A decade of rural physician workforce outcomes for the Rockford Rural Medical Education (RMED) Program, University of Illinois. Acad Med 2013; 88:1941-7. [PubMed][CrossRef]

29. Magnus JH, Tollan A. Rural doctor recruitment: does medical education in rural districts recruit doctors to rural areas? Med Educ 1993; 27: 250-3. [PubMed][CrossRef]

30. Mathews M, Ryan D, Samarasena A. Early-career work location of Memorial University medical graduates: Why the decline in rural practice? Can J Rural Med 2017; 22: 54-61. [PubMed]

31. Matsumoto M, Inoue K, Kajii E. Long-term effect of the home prefecture recruiting scheme of Jichi Medical University, Japan. Rural Remote Health 2008; 8: 930. [PubMed][CrossRef]

32. Matthews C, Bagg W, Yielder J et al. Does Pukawakawa (the regional-rural programme at the University of Auckland) influence workforce choice? N Z Med J 2015; 128:35-43. [PubMed]

33. May J, Brown L, Burrows J. In-place training: Optimizing rural health workforce outcomes through rural-based education in Australia. Educ Sci (Basel) 2018; 8: 20. [CrossRef]

34. McDonnel Smedts A, Lowe MP. Clinical training in the top end: impact of the Northern Territory Clinical School, Australia, on the Territory's health workforce. Rural Remote Health 2007; 7: 723. [PubMed]

35. McGirr J, Seal A, Barnard A et al. The Australian Rural Clinical School (RCS) program supports rural medical workforce: evidence from a cross-sectional study of 12 RCSs. Rural Remote Health 2019; 19: 4971. [PubMed][CrossRef]

36. McGrail MR, O'Sullivan BG, Russell DJ. Rural training pathways: the return rate of doctors to work in the same region as their basic medical training. Hum Resour Health 2018; 16: 56. [PubMed][CrossRef]

37. McKillop A, Webster C, Bennett W et al. Encouragers and discouragers affecting medical graduates' choice of regional and rural practice locations. Rural Remote Health 2017;17: 4247. [PubMed][CrossRef]

38. Moore M, Burgis-Kasthala S, Barnard A et al. Rural clinical school students do come back: But it may take time. Aust J Gen Pract 2018; 47: 812-4. [PubMed][CrossRef]

39. Murray J, Penner C, Heide W et al. Trajectories of physicians in Manitoba, Canada: the influence of contact points of rural-focused professional learning. Can Med Educ J 2018; 9: e93-101. [PubMed][CrossRef]

40. Myhre DL, Bajaj S, Woloschuk W. Practice locations of longitudinal integrated clerkship graduates: a matchedcohort study. Can J Rural Med 2016; 21: 13-6. [PubMed]

41. O'Sullivan B, McGrail M, Russell D et al. Duration and setting of rural immersion during the medical degree relates to rural work outcomes. Med Educ 2018; 52: 803-15. [PubMed][CrossRef]

42. O'Sullivan BG, McGrail MR, Russell D et al. A review of characteristics and outcomes of Australia's undergraduate medical education rural immersion programs. Hum Resour Health 2018; 16: 8. [PubMed][CrossRef]

43. Pagaiya N, Kongkam L, Sriratana S. Rural retention of doctors graduating from the rural medical education project to increase rural doctors in Thailand: a cohort study. Hum Resour Health 2015; 13: 10. [PubMed][CrossRef]

44. Pathman DE, Konrad TR, Ricketts TC. Medical education and the retention of rural physicians. Health Serv Res 1994; 29:39-58. [PubMed]

45. Playford DE, Cheong E. Rural Undergraduate Support and Coordination, Rural Clinical School, and Rural Australian Medical Undergraduate Scholarship: rural undergraduate initiatives and subsequent rural medical workforce. Aust Health Rev 2012; 36:301-7. [PubMed][CrossRef]

46. Playford D, Puddey IB. Interest in rural clinical school is not enough: Participation is necessary to predict an ultimate rural practice location. Aust J Rural Health 2017; 25: 210-8. [PubMed][CrossRef]

47. Playford DE, Evans SF, Atkinson DN et al. Impact of the Rural Clinical School of Western Australia on work location of medical graduates. Med J Aust 2014; 200:104-7. [PubMed][CrossRef]

48. Playford DE, Nicholson A, Riley GJ et al. Longitudinal rural clerkships: increased likelihood of more remote rural medical practice following graduation. BMC Med Educ 2015; 15: 55. [PubMed][CrossRef]

49. Playford $\mathrm{DE}, \mathrm{Ng}$ WQ, Burkitt T. Creation of a mobile rural workforce following undergraduate longitudinal rural immersion. Med Teach 2016;38: 498-503. [PubMed][CrossRef] 
50. Playford D, Ngo H, Atkinson D et al. Graduate doctors' rural work increases over time. Med Teach 2019; 41: 1073-80. [PubMed][CrossRef]

51. Quinn KJ, Kane KY, Stevermer JJ et al. Influencing residency choice and practice location through a longitudinal rural pipeline program. Acad Med 2011; 86: 1397-406. [PubMed][CrossRef]

52. Rabinowitz HK, Diamond JJ, Markham FW et al. Long-term retention of graduates from a program to increase the supply of rural family physicians. Acad Med 2005; 80: 728-32. [PubMed][CrossRef]

53. Rabinowitz HK, Diamond JJ, Markham FW et al. Increasing the supply of rural family physicians: recent outcomes from Jefferson Medical College's Physician Shortage Area Program (PSAP). Acad Med 2011; 86: 264-9. [PubMed] [CrossRef]

54. Ray RA, Woolley T, Sen Gupta T. James Cook University's rurally orientated medical school selection process: quality graduates and positive workforce outcomes. Rural Remote Health 2015; 15:3424. [PubMed][CrossRef]

55. Rhyne RL, Daniels ZM, Skipper BJ et al. Interdisciplinary health education and career choice in rural and underserved areas. Med Educ 2006; 40: 504-13. [PubMed][CrossRef]

56. Rosenblatt RA, Saunders G, Shreffler J et al. Beyond retention: National Health Service Corps participation and subsequent practice locations of a cohort of rural family physicians. J Am Board Fam Pract 1996; 9: 23-30. [PubMed]

57. Rourke J, O'Keefe D, Ravalia M et al. Pathways to rural family practice at Memorial University of Newfoundland. Can Fam Physician 2018; 64: e115-25. [PubMed]

58. Sen Gupta T, Woolley T, Murray R et al. Positive impacts on rural and regional workforce from the first seven cohorts of James Cook University medical graduates. Rural Remote Health 2014; 14: 2657. [PubMed][CrossRef]

59. Smucny J, Beatty P, Grant W et al. An evaluation of the Rural Medical Education Program of the State University Of New York Upstate Medical University, 1990-2003. Acad Med 2005; 80: 733-8. [PubMed][CrossRef]

6o. Tate RB, Aoki FY. Rural practice and the personal and educational characteristics of medical students: survey of 1269 graduates of the University of Manitoba. Can Fam Physician 2012; 58: e641-8. [PubMed]

61. Techakehakij W, Arora R. Rural retention of new medical graduates from the Collaborative Project to Increase Production of Rural Doctors (CPIRD): a 12-year retrospective study. Health Policy Plan 2017; 32: 809-15. [PubMed] [CrossRef]

62. Wendling AL, Phillips J, Short W et al. Thirty Years Training Rural Physicians: Outcomes From the Michigan State University College of Human Medicine Rural Physician Program. Acad Med 2016; 91: 113-9. [PubMed][CrossRef]

63. Wenghofer EF, Hogenbirk JC, Timony PE. Impact of the rural pipeline in medical education: practice locations of recently graduated family physicians in Ontario. Hum Resour Health 2017; 15: 16. [PubMed][CrossRef]

64. Wheat JR, Brandon JE, Leeper JD et al. Rural health leaders pipeline, 1990-2005: case study of a second-generation rural medical education program. J Agromed 2007; 12: 51-61. [PubMed][CrossRef]

65. Woolley T, Cristobal F, Siega-Sur J et al. Positive implications from socially accountable, community-engaged medical education across two Philippines regions. Rural Remote Health 2018; 18: 4264. [PubMed][CrossRef]

66. Zink T, Center B, Finstad D et al. Efforts to graduate more primary care physicians and physicians who will practice in rural areas: examining outcomes from the university of Minnesota-duluth and the rural physician associate program. Acad Med 2010; 85: 599-604. [PubMed][CrossRef]

67. Independent Evaluation of the Rural Health Multidisciplinary Training Program. Orange: KBC Australia, 2020. https://www1.health.gov.au/internet/main/publishing.nsf/Content/rural-health-rhmt-evaluation Lest 24.6.2021.

68. Farmer J, Kenny A, McKinstry C et al. A scoping review of the association between rural medical education and rural practice location. Hum Resour Health 2015; 13: 27. [PubMed][CrossRef]

Publisert: 10. januar 2022. Tidsskr Nor Legeforen. DOI: 10.4045/tidsskr.21.0253

Mottatt 26.3.2021, første revisjon innsendt 19.7.2021, godkjent 1.12.2021.

Publisert under åpen tilgang CC BY-ND. Lastet ned fra tidsskriftet.no 26. april 2023 